\title{
KVALITETA ŽIVLJENJA U SJEVEROZAPADNOJ HRVATSKOJ KROZ POVIJEST S NAGLASKOM NA GRAD VARAŽDIN
}

U članku autorica piše o kvaliteti življenja u sjeverozapadnoj Hrvatskoj kroz povijest koja se stoljećima mijenjala te je drugačija bila na selu u odnosu na grad.

\section{UVOD}

Što je to kvaliteta života i kako se ona može promatrati kroz povijest? Prije nego li odgovorim na ovo pitanje, trebala bih razjasniti što je to kvaliteta života. Postoje različite definicije, i ne postoji jednoznačna definicija, već možemo reći da je kvaliteta života širok višeslojan i složen koncept kojim se bave različite znanstvene discipline, a sama kvaliteta življenja je širi pojam od životnog standarda, jer uključuje cijeli niz čimbenika koji oblikuju ono što cijenimo u životu, a među najvažnijima su: međuljudski odnosi, psihičko i fizičko zdravlje, materijalno stanje, sigurnost, obrazovanje, rad, duhovnost, fizička okolina i stupanj autonomije. Kada se govori o kvaliteti života ili o "dobrom životu“ raspravlja se o primjeni objektivnih i subjektivnih pokazatelja koji govore o kvaliteti života. ${ }^{1}$ Objektivni pokazatelj usredotočen je na proučavanje materijalnog stanja, stanja okoliša, političku slobodu, stupanj demokratičnosti u društvu i sl., a subjektivni pokazatelj pretežno je usmjeren na subjektivne doživljaje i iskustva pojedinca. Jedan od objektivnih pokazatelja je i bruto domaći proizvod i slične ekonomske mjere. Ti ekonomski pokazatelji temeljeni su na nacionalnom prihodu i pružaju informacije o materijalnom blagostanju, ali ne govore o drugim ključnim dimenzijama društva, poput obrazovanja, zdravlja, prirodnog

\footnotetext{
Ljiljana KALITERNA LIPOVČAN, Josip BURUŠIĆ, Maja TADIĆ, „Indikatori kvalitete življenja“ u: Viktor BOŽIČEVIĆ, Siniša BRLAS, Marina GULIN, Psihologija u zaštiti mentalnog zdravlja, Priručnik za psihološku djelatnost i promicanju mentalnog zdravlja, Virovitica, 2012., 438.
} 
okoliša, ljudskih prava i slično. ${ }^{2}$ Osloniti se na mjeru kao što je bruto domaći proizvod i pokušati dati pregled povijesti u korelaciji s kvalitetom života, za jednog povjesničara je vrlo težak posao da ne kažem nemoguć, zbog ne postojanja izvora, tekstova, primjera, ne konzistentnog vođenja podataka, ne postojanja statističkih baza, teritorijalne rascjepkanosti Hrvatske kroz prošlost, ne usporedivosti ali i zbog činjenice da se do 20. stoljeća kvaliteta življenja rijetko spominjala, što dovodi do nemogućnosti ili poteškoća u uspoređivanju rezultata iz stoljeća u stoljeće. Odnosno današnje određivanje kvalitete života nije primjenjivo na prošlost. Kao humanisti možemo uzeti i Aristotelovu tvrdnju da većina osoba oplemenjuje i poboljšava shvaćanje dobrog života ili doživljaj dobra i kreposti što čini čovjeka da bi bio sretan. Ali to što čini sreću je materija po kojoj se ljudi razlikuju. Možemo reći da je Aristotel utvrdio da kvaliteta života znači različite stvari među raznim narodima, a varira od osobe do osobe, ovisno o situaciji. Svjetska zdravstvena organizacija je 1948. deklarirala kvalitetu života definicijom zdravlja, a to je stanje kompletnog fizičkog, mentalnog i socijalnog blagostanja. Druge definicije povezuju zdravlje i kvalitetu života sa srećom i zadovoljstvom u životu. Isto tako razni ljudi zavisno od njihovog okružja podrazumijevaju razne stvari pod kvalitetom života. ${ }^{3}$ I tako bismo mogli u nedogled, zbog toga smo ovdje za potrebe ovog teksta, jednostavno usporedili načine života, stanovanja, običaja između sela i grada kroz povijest od 18. stoljeća do danas pokušavajući opisati kako su se svakodnevne navike mijenjale iz stoljeća u stoljeće i kako ono što je bilo kvalitetno i jedino dostupno u 18. stoljeću, u 19. više nije, a pogotovo u 20. i 21. stoljeću. Prije nego li krenemo sa usporedbom postavlja nam se i pitanje što je to teritorijalno sjeverozapadna Hrvatska. Državni zavod za statistiku je u suradnji s Eurostatom odredio da u sjeverozapadnu Hrvatsku danas spadaju ove županije: Grad Zagreb, Zagrebačka županija, Krapinsko-zagorska županija, Varaždinska županija, Koprivničko-križevačka županija i Međimurska županija. ${ }^{4}$ Pojam sjeverozapadna Hrvatska u prošlosti bio je drugačije teritorijalno određen, odnosno sjeverozapadna Hrvatska je u ranom srednjem vijeku bila prostor omeđen Murom i Dravom na sjeveru, Sutlom, Žumberačkom gorom/Gorjancima i gornjim tokom Kupe na zapadu, kupskim razvođem s porječjima Korane, Mrežnice, Dobre i Gline i obroncima Velike Kapele, Petrove gore i Zrinske gore na jugu te

2 Lana SLAVUJ, „Objektivni i subjektivni pokazatelji u istraživanju koncepta kvalitete života“, Geoadria, 17/1, Zadar, 2012., 73.-92.

3 Josip ČIČEK, „,Kvaliteta života u suvremenim uvjetima u Republici Hrvatskoj s posebnim osvrtom na Bjelovarsko-bilogorsku županiju“, Radovi Zavoda za znanstvenoistraživački i umjetnički rad u Bjelovaru, sv. 7., Bjelovar, 2013., 239.-250.

4 https://hr.wikipedia.org/wiki/Sjeverozapadna_Hrvatska (pristup ostvaren 30. siječnja 2017.) 
slavonskim sredogorjem s padinama Psunja i Papuka na istoku. ${ }^{5}$ Zbog teritorijalne širine, mnoštva gradova (Koprivnica, Ludbreg, Križevci, Krapina, Čakovec i dr.) i sela u ovom radu je naglasak stavljen na Varaždin i njegovu okolicu u razdoblju od 18. stoljeća do danas. Isto tako, moramo naglasiti kada govorimo o kvaliteti življenja u sjeverozapadnoj Hrvatskoj moramo staviti naglasak i na razlike sela i grada koje su u prošlosti bile vrlo izražene, jer je stanovništvo uglavnom do kraja Drugog svjetskog rata živjelo na selu, a manje u gradu, a i same prilike s kraja 18. pa sve do kraja Prvog svjetskog rata nisu se nešto veliko mijenjale. Sve do početka 20. stoljeća ali i nakon, na prostoru sjeverozapadne Hrvatske, naravno, u ruralnim predjelima vrlo se teško živjelo.

\section{KVALITETA ŽIVOTA NA SELU}

Na selu, u 18. i početkom 19. stoljeća vladalo je siromaštvo, obitelji su bile mnogobrojne, i većina ih je živjela u sklopu kućnih zadruga. ${ }^{6}$ Zadruga je prema D. Pavličeviću „patrijarhalna ustanova u kojoj živi više obitelji i naraštaja, ravnopravna zajednica života, rada, autarhične proizvodnje i potrošnje na zajedničkom imanju kojom rukovodi demokratski izabrani starješina, a upravlja skupština svih ostalih odraslih punopravnih zadrugara". ${ }^{7}$ U nekim krajevima zadruge su se zadržale skoro do međuratnog razdoblja. ${ }^{8}$ Glava obitelji je bio muškarac, koji je naređivao i određivao podjelu poslova unutar kuće. Podjela poslova na muške i ženske bila je iznimno stroga. ${ }^{9}$ Prema tradicionalnom obrascu od 18. i 19. stoljeća, te cijelo međuratno razdoblje i u nekim područjima i nakon Drugog svjetskog rata tipični ženski poslovi bili su vezani uz kuću i kuhinju: briga o podizanju djece, kuhanje i pranje rublja. Ženama je pripadala i briga oko odjeće, uključujući i pripravu platna,

5 Hrvoje GRAČANIN, Silvija PISK, „Sjeverozapadna Hrvatska u ranom srednjem vijeku“, Povijest Hrvata I., Nova zraka u europskom svjetlu, Hrvatske zemlje u ranom srednjem vijeku (oko 550-oko 1150), urednica Zrinka NIKOLIĆ JAKUS, Zagreb, Matica Hrvatska, 2016., 345.

6 Suzana LEČEK, „Seljačka obitelj u Hrvatskoj 1918.-1960., Metoda usmene povijesti“, Radovi, Zavoda za hrvatsku povijest, vol. 29., Zagreb, 1996., 249.-265.

7 Dragutin PAVLIČEVIĆ, Hrvatske kućne zadruge I. (do 1881), Zagreb, 1989., 23.; Isti, Hrvatske kućnel obiteljske zadruge I., (do 1881.), drugo, ponovljeno izdanje, Golden Marketing-tehnička knjiga, Zagreb, 2010., 23. Zadruga se zasniva na zajedničkom posjedu koji se ne dijeli nakon očeve smrti, starješina se bira po demokratskom načelu i on određuje i raspoređuje poslove. Uz njega postoji i ženska pomoćnica koja vodi ,"ženski“ dio zadruge, zajedničko im je vlasništvo svih sredstava za proizvodnju, iako uz to postoji i pojedinačno vlasništvo kao sporedno. Također postoji zajednički stol svih zadrugara za koji prvo sjedaju odrasli družinari, pa žene i napokon djeca.

8 Vidi: Milivoj REĐEP, Miroslav ŽUGAJ, „Kućne zadruge u Varaždinskoj županiji u drugoj polovici 19. i početkom 20. stoljeća“, Radovi Zavoda za znanstveni rad HAZU Varaždin, br.4.-5., 1990.-1991., 89.-110.

9 Ivana JUKIĆ, Maja KATUŠIĆ, "Svakodnevlje“, U potrazi za mirom i blagostanjem, Hrvatske zemlje u 18. stoljeću, ur. Lovorka ČORALIĆ, Povijest Hrvata, sv. 5., Zagreb, Matica hrvatska, 2013., 239. 
šivanje i vezanje. Njihov posao je bio i vrt, briga oko peradi, svinja i krava. Kako je uz to bila vezana i trgovina tih proizvoda, i to bio ženski posao. Uz obaveze u kući i vrtu, najteži je ženski posao na polju bilo okopavanje kukuruza, a na manjim površinama pod žitaricama i žetva. Iako je vinograd smatran muškim područjem, žene su u njemu obavljale jednostavnije poslove kao što je okopavanje. Muški poslovi bili su teži fizički poslovi na polju i vinogradu (oranje, košnja, prijevoz kolima) ali i neki osjetljivi poslovi koji su tražili stručnost (rezanje vinograda ili voćnjaka). Oni su se brinuli za dovoz drva iz šume i sve što je vezano uz pripremu ogrijeva (cijepanje drva, unos u kuću). Muškarci su se brinuli za blago, čistili su i timarili krave, volove i konje. S njima su radili i trgovali. Neke poslove na polju su radili zajedno sa ženama, a muškarce su zapali teži (rad sa zapregom i košnja livada). U vinogradima su sadili, sjekli kolje, rezali, špricali. Muškarci su tradicionalno obavljali i sve poslove vezane uz odnos sa širim društvom: odlazak na sud, općinu i udaljenija sajmišta te praćenje i sudjelovanje u političkom životu. ${ }^{10}$ Seljački posao prilagođavao se klimi i vremenskim prilikama te je ritam bio usklađen sa smjenama godišnjih doba. ${ }^{11}$

Osamdesetih godina 19. stoljeća poljoprivreda je na selu i dalje bila glavno zanimanje. Do početka 20. stoljeća veći dio poljoprivrednog stanovništva posjedovao je mali zemljišni fond usitnjen na male posjede (44,23\% posjeda je 1895 . imalo ispod 5 jutra). Na drugoj strani postojali su ogromni kompleksi zemlje koja je bila u rukama malog broja veleposjednika. Ništa se nije promijenilo ni u međuratnom razdoblju, jer je i dalje većina seljaštva živjela na nerentabilnim gospodarstvima manjim od 5 ha (3 jutra) i vladala je agrarna prenapučenost. Na seljačkim domaćinstvima koristio se gotovo isključivo ručni rad, uz upotrebu volovskih ili konjskih zaprega, a najsiromašniji su uprezali krave. No ipak, proizvodnost sela je rasla ali sporo. Pojavile su se neke proizvodne mogućnosti, udomaćio se željezni plug, pojavila su se nova oruđa. Seljaci su samo teškim fizičkim radom i vlastitim zalaganjem postizali uspjeh u napretku svojeg gospodarstva. Malobrojni su uspjeli okrenuti u svoju korist ono malo što im se nudilo, te su pomoću viška zemlje i (ili) dobrim gospodarenjem i snalažljivosti uzdizali svoje domaćinstvo i time se uzdigli u uzak sloj „,boljih“ obitelji odnosno imućnije seljake. Bogatiji seljaci se nisu posebno izdvajali i dalje su živjeli sličnim načinom života, ali su uživali veći ugled i pripisivala im se veća društvena moć. ${ }^{12}$ Razvojem industrijalizacije i urbanizacijom, dio seoskog stanovništva odlazi na stalni ili privremeni rad u obližnja industrijska središta (Varaždin, Zagreb) ili se zapošljava u malim industrijskim pogonima na selu (Straža kraj Pregrade, rudnici u

\footnotetext{
10 Suzana LEČEK, Seljačka obitelj u sjeverozapadnoj Hrvatskoj 1918.-1941., Zagreb, 2003., 458.-460.

11 Isto, 67.

12 Isto, 33., 53.-57.
} 
Ivancu).$^{13}$ Muškarci su uglavnom radili na nekvalificiranim poslovima u građevinarstvu ili u nekoj od brojnih tvornica, a žene (djevojke) uglavnom su se zapošljavale kao sluškinje kod bolje stojećih građanskih obitelji ili su radile kao dojilje gradskoj djeci, a kasnije su se i one pridružile muškarcima u varaždinskim tvornicama. Grad nije privlačio seljake kao mjesto gdje se bolje živi, nego je bio izlaz kada se kod kuće više nije moglo preživjeti. Većim prihodima koji se donose u kuću mijenjaju se i stambene navike, pa dolazi do potrebe izgradnje novih kuća za stanovanje, ili obnavljanjem ili dogradnjom starih. ${ }^{14}$ Iseljavanje se nastavilo i nakon Drugog svjetskog rata, osobito prema Zagrebu. ${ }^{15}$ Proces modernizacije sela nije išao brzo, što je vidljivo iz nekih istraživanja provedenih na prostoru sjeverne Hrvatske 1981. godine, u svim selima nije bila provedena kanalizacija (u nekima je nema još ni danas), dok su plinofikacija i vodovod bili djelomični, mjesta su bila slabo prometno povezana, a ceste koje su postojale nisu bile asfaltirane. ${ }^{16}$

\section{BRAK I OBITELJ}

Djevojke su sklapale brak u dobi od 18 do 20 godina a mladići od 22 do 26 . Sve poviše toga smatrano je „starom curom“ ili „starim dečkom“. Djevojke bi se uglavnom udavale čim bi postale punoljetne, a mladići su čekali da se vrate iz vojske. Za raniji brak odlučivalo se samo u velikoj nuždi (korizmeno vrijeme ili izvanbračna trudnoća). Izbor partnera nije bio prepušten onom tko se želio vjenčati ili njegovim osjećajima, već su roditelji ili članovi domaćinstva ukoliko je osoba bila član šire i/ili zadružne obitelji odlučivali umjesto bračnog partnera. Prilikom odabira uzimalo se u obzir nekoliko čimbenika kojima se nastojalo osigurati što bolji život budućoj obitelji, a to su imovina, društvena mreža i prihvaćanje volje roditelja. ${ }^{17} \mathrm{U}$ brak se kako je već navedeno ulazilo razmjerno rano, a mladi bračni par je nekih 10 do 15 godina

13 Više o mobilnosti Dražen NJEGAČ, "Oblici prostorne mobilnosti stanovništva Hrvatskog zagorja“, Geografski glasnik, 57, Zagreb, 1995., 93.-109.

14 Nada DEŽELIĆ, Mirna ZEBEC, Josipa KERN, Željko PANTIĆ, „ZZdravstveno -ekološki aspekti stanovanja u selima Hrvatskog zagorja“, Sociologija sela, 22, 83/86, Zagreb, 1984., 73.-83.; S. LEČEK, Seljačka obitelj, 277.

15 D. NJEGAČ, „Oblici prostorne mobilnosti“, 93.-109.

16 N. DEŽELIĆ, M. ZEBEC, J. KERN, Ž. PANTIĆ, n. dj. 77.- 83. Primjer sela Belec. Prema anketi provedenoj 1981. godine u selima tadašnje mjesne zajednice Belec u Hrvatskom zagorju vidljivo je da vodovodnu vodu imalo 80\% domaćinstava, nijedno naselje nije imalo javnu kanalizaciju, a bilo je i malo kućnih kanalizacija, najviše je procijednih jama i nešto septičkih. Slaba je opremljenost kuća bila i sa zahodom. Najveći broj kuća imao je zahod u dvorištu (51,7\%), a najmanje u kući (16,3\%). Vodovod u naselju i u kući nije utjecao na čistoću stana i okućnice, jer je prema istraživanjima čistoća bila jednako loša u svim kućama bez obzira imala kuća vodovod ili ne imala, bila stara ili nova.

17 S. LEČEK, Seljačka obitelj, 418.-439. 
živio u domaćinstvu s muževim roditeljima i braćom i tek bi se onda odjeljivao i započinjao vlastiti život. Ženilo se unutar uskog i jasnog prostornog kruga: župe ili nekoliko okolnih sela, onoliko koliko je svakodnevna komunikacija mogla obuhvatiti. Dok nisu stigla djeca, mladi su se još i mogli vidjeti na zabavama, no nakon djece, radne obaveze više im nisu dopuštale priliku za izbivanje iz kuće. ${ }^{18}$ Ukoliko su doživjeli starost koja je na selu okvirno određena granicom od 60 godina, stariji ljudi su živjeli najčešće sa svojom djecom, a njihov položaj ovisio je o dva čimbenika: da li su uopće mogli birati žele li živjeti sami ili s djecom te kolika je bila njihova gospodarska važnost u zajedničkom domaćinstvu. Bez ikakva drugog izvora prihoda (mirovina, socijalna pomoć), starije osobe su mogle jedino živjeti onako kako su to činile cijeli svoj život od zemlje, i u zajednici s mlađima. Na selu je postojala moralna obaveza da je neosporno da se mladi brinu o starijima i nije se moglo dogoditi da starci pored žive djece potraže zaštitu nekog drugog, a onaj koji je obavezu preuzeo na sebe uglavnom ju je i izvršavao. Društvene norme su bile jasne: starije se poštovalo. Dok su starci (najstarija glava obitelji, otac) bili živi, oni su bili i glava obitelji. Bake bi ljubomorno držale kućanstvo, a djedovi bi vodili poslove (najteže poslove prestali bi obavljati čim bi mlađa generacija mogla ih preuzeti na sebe), upravljali gospodarstvom i donosili odluke. Do smjene vlasti došlo bi postupno, kada bi starce na to natjerala tjelesna ili druga slabost. ${ }^{19} \mathrm{U}$ međuratnom razdoblju dolazi i do promijene odnosa i statusa supružnika, što je dovelo i do nove prakse u nasljeđivanju zemlje i izmijenjenom ulogom žene. Zemlju su uglavnom nasljeđivali izravni muški nasljednici ili je sam vlasnik zemlje imao pravo odlučivati o nasljednicima. Tamo gdje je bilo ikako moguće, zemlja se ostavljala sinovima, a kćerima se davala samo tradicionalna oprema. Ubrzo je i zemlja počela ulaziti u miraz, pa ukoliko kćer nije mogla dobiti zemlju, smatralo se da mora dobiti isplatu, pa makar s vremenskim odgodom. ${ }^{20}$

\section{PREHRANA}

Siromaštvo je u 19. stoljeću određivalo način prehrane, pa je prehrana bila jednolična i nedostatna, odnosno, jelo bi se samo ono što je izraslo na vlastitoj zemlji ili se uzgojilo u vlastitom dvorištu. ${ }^{21}$ Do Prvog svjetskog rata na selu trgovalo se neznatno malo, uglavnom vinom, a ponekad i stokom, peradi ili jajima. Od zarađenog novca platio bi se porez i kupila pokoja litra jestiva ulja i petroleja za rasvjetu te malo soli i šećera, a samo o velikim crkvenim blagdanima ili obiteljskim svečanostima

\footnotetext{
18 Isto, $430 .-433$.

19 Isto, 477.- 482.

20 Isto, 512.-513.

21 Isto, 67.
} 
(vjenčanje ili krštenje djeteta) na stolu bi bilo goveđe juhe ili kupljena mesa. Kruh se pekao jedanput tjedno a kolači nekoliko puta godišnje. Kuhinjski inventar nije bio velik: krušna peć, dva do tri zemljana lonca, drvena zdjela i žlica, te poneka vilica. Kruh bi se mijesio uglavnom od pšeničnog i kukuruznog brašna, s time da se najviše sijao kukuruz. Pšenica i ostale žitarice su se nešto manje sijale, a od povrća se sadio krumpir, kupus, grah, bob, leća i repa, što je bilo osnova prehrane seljaka tijekom cijele godine. Svježe, ubrano voće jelo se vrlo rijetko. Voće se sušilo te se poslije dodavalo kao dodatak drugim jelima. Meso kao što je pečena svinjetina i perad, jela se samo u najsvečanijim prilikama ili prilikom kolinja. Malo se toga kupovalo, jer je izvor sirovina bio vrt, vlastito polje, svinjac odnosno kokošinjac. Način pripremanja hrane bio je vrlo jednostavan i nemaštovit. U zimi i u proljeće jelo se tri puta na dan, a ljeti kada se dulje radilo i četiri do pet puta dnevno. Pripremljena hrana se nije bacala. Nakon Prvog svjetskog rata sa imućnijih gospodarstva, sinovi su odlazili na školovanja, pa su stjecali i nova znanja o obradi polja, uzgoju loze, voćarstvu, općenito poljoprivredi, koja su po povratku na selo i primjenjivali, što je znatno unaprijedilo poljoprivrednu proizvodnju i povećalo standard sela. U razdoblju između dva svjetska rata sijalo se sve kao i ranije, jedino je pšenice bilo znatno više. Smanjuje se proizvodnja leće i boba, a seljaci više sade rajčicu, papriku i grašak. Kuha se s više masti, suhe dimljene slanine i mesa. Jelovnik postaje raznovrsniji. Na stolu je više mesa i to pirjanoga, pečenoga ili pohanoga. Iz grada na stol stiže riža. Poboljšava se prehrana i jelovnik. Glavna je hrana zimi, kao i u prijašnjem razdoblju, kisela repa ili kiseli kupus u kojoj se kuha svježe ili suho meso. Poslije Drugog svjetskog rata uvode se nove kulture, rajčica, paprika, nove vrste salata i po dvije vrste zelja, nova povrća na primjer kelj, poriluk i mahune. Tu i tamo sadi se plavi patliđan. Krumpir postaje nezamjenjiv prilog jelima od mesa i sve češće se kupuje riža i gotova suha tjestenina. Jelovnik se obogaćuje ribom. Mnoge se navike mijenjaju nakon Drugog svjetskog rata pod utjecajem brzih promjena u privrednom i društvenom razvoju općenito. Električna struja i industrijalizacija uvjetuje djelomično napuštanje poljoprivrede. Seljaci postaju radnici, koji svaki dan putuje na posao u obližnje mjesto, pa im malo vremena ostaje za obradu zemlje, te se seljak orijentira samo na obrađivanje vrta s povrćem, nekih manjih oranica i vinograda. Šezdesetih i sedamdesetih godina 20. stoljeća seljaci napuštaju zemlju, a novodoseljenici koji se iz grada preseljavaju na selo više se ne bave uzgojem stoke ili obradom zemlje. Na selo stižu hladionici i zamrzivači, pa suvremeni stanovnici sela hranu spravljaju kao u gradu. $S$ jelovnika nestaju tradicionalna domaća jela. ${ }^{22}$

22 Božica SOMEK-MACHALA, „Utjecaj kulturnih promjena na prehranu stanovništva uz Sutlu“, Studia ethnologica, vol. 1., Zagreb, 1989., 202. -206.; S. LEČEK, Seljačka obitelj, 60.-67. 


\section{STAMBENE PRILIKE}

Stambene prilike iz 19. i početkom 20. stoljeća nisu se previše razlikovale. Seoski dom bio je skroman. I to ne samo u našim krajevima nego i u europskim. Bila je to često jednoprostorna drvena kuća pravokutnog tlocrta s ognjištem u sredini. ${ }^{23}$ Kuće su bile prizemnice, ne baš prostrane, često je u jednoj sobi spavalo i do desetero osoba. ${ }^{24}$ Pored kuće (hiže) nalazio se štagalj, s košem-kuružarom i ostalim manjim zgradama. Dvorište nije imalo posebne ograde, ali je bilo okruženo voćnjakom (trnacom) u kojem su se sadile šljive, pokoja jabuka i kruška. Samo je vrt bio odijeljen od dvorišta slabom ogradicom ili plotom. ${ }^{25} \mathrm{U}$ međuratnom razdoblju i dalje prevladavaju niske prizemnice, s dvije ili rjeđe, tri prostorije. Obavezna je bila kuhinja i velika polifunkcionalna soba u kojoj se odvijao cjelokupni život: tu se spavalo, jelo, radilo, primalo goste. Ponekad je postojala i mala "komora“ u kojoj je spavao mladi bračni par (reproduktivni članovi) ili je služila za spremište. Pod je bio zemljani, rjeđe drveni, prozori mali, zidovi oblijepljeni vapnom koje se obnavljalo jednom ili dva puta godišnje. Krov se prekrivao slamom, rjeđe crijepom. Kreveta je bilo malo i ukoliko su obitelji bile mnogobrojne, spavalo se na podu. Dječaci su ljeti spavali u štali i to u odijelu u kojem su bili preko dana (izvještaj iz 1940.). ${ }^{26}$ Niti početkom 20. stoljeća nije bilo velikih promjena, tek razvitkom industrijalizacije i urbanizacije u pojedinim seoskim sredinama dolazi do poboljšanja životnih i zdravstvenih uvjeta. Seoska područja tek od osamdesetih godina 20. stoljeća doživljavaju značajne demografske, gospodarske i društvene promjene. U gradnji kuća počinje prevladavati kombinirana građa: betonski blokovi, opeka, kamen i drvo. Kuće građene poslije 1950. veće su i njihova površina je između 70-110 m2, dok su se prije površine kuća kretale između 40-60 m2. Kuće su katnice i relativno velike stambene zgrade. Do 1960-ih godina obitelji su imale 4-5 članova, a gospodarskim napretkom dolazi do smanjenja članova. ${ }^{27}$

\section{SOCIJALNE I ZDRAVSTVENE PRILIKE}

U 18. stoljeću i dijelom 19. stoljeća loši životni uvjeti, jednolična prehrana kao i slaba zdravstvena zaštita pogodovali su razvoju raznih bolesti na selu (tifus, dizenterija, groznica, malarija, tuberkuloza, spolne bolesti) koje su sa sobom odnosile brojne

\footnotetext{
Zdravko ŽIVKOVIĆ, Hrvatsko tradicijsko graditeljstvo, Zagreb, 2013., 6.

Isto, 6 .

Isto, 131.

26 S. LEČEK, Seljačka obitelj, 289.-290., Vidi bilješku u knjizi 336.

27 N. DEŽELIĆ, M. ZEBEC, J. KERN, Ž. PANTIĆ, n. dj. 73.-83.
} 
žrtve, a prijetile su često i raznorazne epidemije što je dovodilo do visoke stope smrtnost, osobito u dječjoj dobi. ${ }^{28}$ Kuće su bile malene, drvene, svaka je u svojem stražnjem dvorištu imala gospodarske objekte iza kojih su se nastavljali vrtovi, voćnjaci i oranice. Ne rijetko su u istim prostorijama stanovali i ljudi i blago. Sanitarni i higijenski uslovi bili su skoro pa nepoznati, a o socijalnoj sigurnosti nema govora. U međuratnom razdoblju higijena je na mala vrata prodirala na seljačka gospodarstva no još uvijek su se mogle naći kuće zadimljenih i mračnih soba, prljavih podova, bez sanitarnog čvora i sa zapuštenom djecom. ${ }^{29}$ Odijevali su se vrlo skromno. Veći dio godine seljaci su hodali bosi, a mnogi nisu imali odgovarajuću odjeću i obuću. Nije bila rijetkost da djeca koja još ne idu u školu uopće nemaju cipele. Odjeća se radila kod kuće jer su brojni seljaci kupovali od seoskih obrtnika gotovo platno ili su kupovali materijal te ga davali tkati. Tko je mogao kupovao je pamuk. Kupljenu odjeću prvo su počeli kupovati muškarci, a potom žene i to marame, pregače, bluze i vunene veste. Kupljena odjeća nalazila se i kod siromašnijih i bogatijih obitelji. Siromašniji bi zbog odlaska u grad raspolagali s nešto novca pa su imali mogućnost kupovine odjeće, osobito je to bilo vidljivo kod djevojaka koje su boljom odjećom željele pokazati da su poželjan bračni partner, dok su bogatiji odjećom željeli pokazati svoj bolji status. ${ }^{30}$

Zdravstvena zaštita bila je minimalna, liječnika si je mogao omogućiti samo onaj tko je imao novaca. Prva bolnica u varaždinskom kraju otvorena je u svibnju 1890. u selu Možđencu nedaleko Novog Marofa zahvaljujući supruzi grofa Rudolfa I. Erdödya, Lujzi rođ. Drasche von Wartinberg. Ona je bila velika dobrotvorka i na raskršću državne i kotarske ceste koja vodi prema mjestu Ljubešćica, u zgradi sagrađenoj 1780. otvorila je prvu karitativnu ustanovu (bolnicu) i namijenila ju je liječenju stanovnika novomarofskog kraja bez obzira na njihovo imovno stanje. Sve troškove liječenja i smještaja snosila je obitelj Erdödy. Uz bolnicu je postojala i ambulanta kamo su se mogli obraćati za pomoć okolni stanovnici. Ondje su imali besplatan pregled, lijekove i liječenje. Bolnica je postojala do kraja Prvog svjetskog rata. Grofica je u studenom 1890. u župnom dvoru u Mađarevu otvorila i kuhinju za prehranu školske djece. Kasnije su se pojavile i bolnice u Krapini, Klanjcu, Bednji, Vinici i Varaždinu, ${ }^{31}$ s izuzetkom bolnice u Krapinskim Toplicama koja je osnovana 1860. godine.

28 I. JUKIĆ, M. KATUŠIĆ, „Svakodnevlje“, 234.

29 S. LEČEK, Seljačka obitelj, 293.

30 S. LEČEK, Seljačka obitelj, 296.-301.

31 Gustav PISEK, „Nekoliko podataka o bolnicama Varaždinske županije u prošlosti“, Muzejski vjesnik, Glasilo Muzejskog društva sjeverozapadne Hrvatske, 11, ožujak, Varaždin, 1988., 50.-53. 


\section{ŠKOLOVANJE I DRUŠTVENI ŽIVOT}

Budući da se na djecu osobito u siromašnijim obiteljima vrlo rano računalo kao na pomoćnu radnu snagu, školovanje nije bilo prioritet. ${ }^{32}$ Dok je većina seoske djece u 19. stoljeću bila nepismena, u međuratnom razdoblju nekolicina ipak uspijeva steći osnovno obrazovanje. Između dva svjetska rata, školovanje je bilo osnovno, a škola nerijetko udaljena po nekoliko kilometara pa djeca uglavnom nisu pohađala školu ili su pohađala samo pučku školu (do 11 godina) kako bi naučila barem pisati i čitati. Zahvaljujući seoskim župnicima su se iz siromašnih seoskih obitelji izdvojili pojedinci kojima je omogućeno ne samo osnovno obrazovanje, već su neki od njih završili gimnazije i fakultete. Osnovnu je školu u to doba završavalo otprilike 10 posto seljačke djece. ${ }^{33}$ Situacija se popravlja na selu nakon završetka Drugoga svjetskog rata no i tada postoje seoske obitelji koje omogućuju svojoj djeci samo osnovno obrazovanje.

Pravo na rad bila je najvažnija vrijednost koja je omogućavala bolju kvalitetu življenja, odnosno dok si bio sposoban za rad, mogao si osigurati najosnovnija sredstva za svakodnevni život. Budući da se u seoskim sredinama teško radilo, odnosno sve se radilo ručno, nije bilo slobodnog vremena, a zabava kao takva pojavila se tek u međuratnom razdoblju. Društveni život na selu skoro da nije postojao, izuzev ponekad odlaska u gostionicu u većem mjestu. Tek u međuratnom razdoblju kada se pojavljuje već broj zaposlenih koji odlaze u grad, javlja se i drugačiji društveni život. Tada, zaposleni znaju sa suprugama i prijateljima iz sela otići zajedno u susjedno mjesto u gostionicu na zabavu, što je posve novo shvaćanje slobodnog vremena i korištenja novca za zabavu. ${ }^{34}$ Pravo zabave pripadalo je svim mladima, no postojale su značajne razlike i sloboda pri izboru i trajanju zabave kod djevojaka i kod mladića. Djevojke su imale prije svega strogu kontrolu kretanja. Do starosti od 11 ili 12 godina stroga podjela na muško - žensko nije postojala, međutim odrastanjem stariji dječaci imaju mogućnost sve dužeg ostajanja vani, dok djevojčice prestaju dolaziti na druženje i igranje. Česta vrsta zabave u mladenačkim danima bilo je zajedničko pjevanje. Mladićima je bilo dopušteno i svakodnevno okupljanje, pjesma, ostajanje vani do dugo u noć, a ponekad i do jutra, dok su djevojke bile strože nadgledane osobito ako su dolazile iz imućnijih obitelji. Tada su bile pod strogim nadzorom. Na selu je djevojkama najveća zabava bilo komušanje kukuruza kada se znalo skupiti i po tridesetak mladih. Uobičajene zabave bile su proštenja, svadbe, nedjeljni ples, zatim okupljanje oko komušanja kukuruza i sličnih zimskih

\footnotetext{
32 S. LEČEK, Seljačka obitelj, 356.-357.

33 B. SOMEK-MACHALA, n.dj., 202.

34 S. LEČEK, Seljačka obitelj, 301.
} 
društvenih poslova, a često i članstvo u nekom od postojećih društava (uglavnom vatrogasnih) u svojem ili susjednim mjestima..$^{35} \mathrm{U}$ takvom okružju u većini seoskih sredina o kvalitetama života koje danas postoje nije se previše razmišljalo, niti govorilo. Takvo stanje, uz izuzetke, vladalo je na selu pa skoro do sredine 20. stoljeća, a u krajevima koji nisu bili dobro prometno povezani i kasnije sve do sedamdesetih godina 20. stoljeća. U nekim selima nalazile su se plemićke kurije i vlastelinski dvorci, međutim stanovnici tih zdanja imali su drugačiju kvalitetu života koja nije imala sličnosti sa životom seljaka, već je njihova kvaliteta života sličnija onoj u gradu iako ne u svim segmentima, jer su i u gradu postojale razlike između siromašnijih i imućnijih slojeva, između radnika, zanatlija, trgovaca, građana i plemstva. Vlastelini su znatnim dijelom godine boravili na svojim posjedima i njihov svakodnevni život bio je ritmiziran ciklusom radova na imanju pri čemu su sjetva, žetva i berba predstavljale važne aktivnosti. Život na veleposjedu bio je složen i živ, a kvaliteta življenja vlastelina ovisila je i o njegovoj ekonomskoj sposobnosti. ${ }^{36}$

\section{KVALITETA ŽIVOTA U GRADU - PRIMJER VARAŽDINA IZGRADNJA GRADA U 18. STOLJEĆU}

U usporedbi sa selom, nešto je drugačija kvaliteta života kod pojedinaca koji su nastanjivali grad u 19. i početkom 20. stoljeća, mada niti građani o kvaliteti života nisu razgovarali ali su poduzimali korake da si „uljepšaju“ kvalitetu života, ne samo u osobnom životu, već su uređivali i okolinu u kojoj su živjeli.

Ovdje ćemo kao primjer uzeti Varaždin, koji je bio centar cijele sjeverozapadne Hrvatske, no mogli bismo govoriti i o nekim manjim gradovima i mjestima kao što su Krapina, Pregrada ili Stubica. Grad Varaždin je, uz Zagreb, najveći grad sjeverne Hrvatske i predstavlja regionalno i funkcionalno središte. Njegova povoljna lokacija i povoljni prometni položaj jedan su od temeljnih čimbenika njegova razvoja. Osim geografskog i prometnog položaja, ključni razvojni čimbenik Varaždina je i njegov geopolitički položaj, a to je blizina granice, nekad Štajerske i Ugarske, a danas Slovenije i Mađarske. Nastao je u srednjem vijeku na sjecištu nekadašnjih rimskih putova. Prvi spomen grada nalazimo 1181. godine u povelji Bele III., gdje se Varaždin spominje kao sjedište županije. Poveljom Andrije II. Arpadovića iz 1209. Varaždin dobiva status slobodnog kraljevskog grada. Zbog svojeg povoljnog položaja u srednjem vijeku Varaždin postaje jedno od najznačajnijih trgovačkih i obrtnih središta Hrvatske sa snažno razvijenim građanskim slojem stanovništva. U 16. stoljeću dolazi

S. LEČEK, Seljačka obitelj, 404.-416.

36 Iskra IVELJIĆ, Anatomija jedne velikaške porodice. Rauchovi, FF press, Zagreb, 2014., 105.-120. 
do prekretnice u razvoju grada zbog prodora Osmanlija i Varaždin tada prerasta u glavnu utvrdu i sjedište Slavonske vojne granice te kao takav postaje obrambeni štit ne samo Hrvatskog Kraljevstva već i susjedne Štajerske. Sjedište Slavonske vojne granice ostaje sve do 1731. godine iako formalno nije više u sastavu Vojne granice od 1578. godine. Tijekom tih dva stoljeća razvoj grada bio je potaknut uglavnom njegovim vojnim funkcijama, a istodobno status slobodnog kraljevskog grada omogućavao mu je dobre uvjete za daljnji razvoj obrtničko-trgovačke tradicije. ${ }^{37}$ Već u drugoj polovici 16. stoljeća Varaždin izbija na prvo mjesto po broju stanovnika, a i u privrednom pogledu je nadmašio Zagreb, odnosno tadašnji Gradec. ${ }^{38}$ Grad je tada s predgrađima brojio oko 600 kuća (od toga broja 100 kuća nalazilo se unutrašnjem gradu, u prostoru utvrđene jezgre) u kojima je živjelo oko 2200 stanovnika. ${ }^{39}$ Udaljavanjem od osmanske granice, (1699.) grad gubi funkciju pogranične utvrde i u punoj mjeri afirmira svoj dobar geoprometni položaj na pravcu glavnih trgovačkih i prometnih putova. Zahvaljujući, stabilnom i sigurnom razvoju, Varaždin tijekom 18. stoljeća doživljava svoj najveći procvat, prerastajući u najbogatiji i najrazvijeniji barokni grad kontinentalne Hrvatske. U razdoblju od 1756. do 1776. preuzima i funkciju glavnoga grada Hrvatske. Prema Jozefinskom popisu 1785./7. Varaždin je bio najveći grad kontinentalne Hrvatske sa 4402 stanovnika dok je Gradec tada imao 2815. ${ }^{40}$ Erdeljski putopisac Dominik Teleki je godine 1795. putovao zapadnim pokrajinama tadašnje Ugarske i tom prilikom posjetio je Varaždin. Opisao ga je u svojem putopisu: „ (...) gradske ulice su prilično redovite i popločene. U njemu se nalaze značajne zgrade Palača županije. Tako skladnih ima čak i u Ugarskoj malo. Zatim palača grofova Drašković, gradska vijećnica, crkava. Kojih za tako malo mjesto ima zaista previše. Tu je stara župna crkva, franjevačka s mnogo pozlate, pavlinska sa velikim samostanom. Prilično prostrano predgrađe, koje okružuje četvorinu unutarnjeg grada, ima također lijepih zgrada, kuća i vrtova“. ${ }^{41}$

Gospodarski razvoj Varaždina u 18. stoljeću omogućio je njegovu bržu izgradnju, ali i demografski rast. Isto tako politički i gospodarski uspon grada potaknuo je njegovu snažnu urbanističko-arhitektonsku preobrazbu. ${ }^{42}$ Od sredine 18. stoljeća Varaždin doživljava i značajne promjene u komunalnom uređenju grada, popravljaju

\footnotetext{
37 Mirela SLUKAN ALTIĆ, Povijesni atlas gradova, VARAŽDIN, V. svezak, Institut društvenih znanosti Ivo Pilar, Državni arhiv Varaždin, Varaždin, 2009., 9.

38 Neven BUDAK, „Pogranična gradska naselja sjeverne Hrvatske u 17. Stoljeću“, Radovi, Zavoda za hrvatsku povijest Filozofskog Fakulteta, 25, Zagreb, 1992., 27. -30.

39 Ratko VUČETIĆ, „Predmoderni grad sjeverozapadne Hrvatske-primjer Varaždina“, Radovi Instituta za povijest umjetnost, 31., Zagreb, 2007, 135.

40 Isto, 146.

41 Ante E. BRLIĆ, „U Međimurju i Varaždinu 1795.“, Muzejski vjesnik, Glasilo Muzeja sjeverozapadne Hrvatske, 4,Varaždin, veljača 1981., 57.-58.

42 R. VUČETIĆ, „Predmoderni grad“, 137.-142.
} 
se ceste, uređuju se pločnici, nastaje groblje 1773. koje je danas jedno od najpoznatijih klasicističkih parkova kulture. Kako su jedno vrijeme u Varaždinu bile administrativne funkcije, one su utjecale na socijalnu strukturu grada, jačaju trgovci i obrtnici i useljavaju se značajni ljudi i velikaši koji počinju graditi u jezgri grada svoje palače u novom rokoko stilu. Od polovice 18. stoljeća pa sve do katastrofalnog požara u gradu je izgrađen niz značajnih velikaških građevina. Značajno da su graditelji javnih zgrada i nekih sakralnih objekata bili domaći varaždinski zidarski majstori. ${ }^{43}$ Grade se jednokatnice, potom dvokatna palača Patačić, palače Drašković, DraškovićNadasdy, Erdödy-Oršić, Keglević, Patačić-Puttar, Petković-Ožegović, Batthanyi, Prassinszky-Sermage, Herczer, Erdödy-Patačić. Grade se znamenitije kuće građana, kao što je kuća Fritz-Friederich. ${ }^{44}$ Uslijed toga dolazi i do promjena na središnjem gradskom trgu, gdje trg postaje reprezentativni prostor okružen palačama. Trgovina je preseljena u stacionarne dućane u prizemljima trgovačkih kuća, dok su obrtnici izmješteni u sporedne ulice. Palače se grade ne samo s namjerom da budu reprezentativni stambeni prostor, već i da donose prihode vlasniku. U gornjem dijelu palače živjeli su „podstanari“ dok se prizemlja iznajmljuju za različite djelatnosti. U gradu žive građani koji imaju svoja građanska prava međutim, useljava se i plemstvo, no ono i dalje želi zadržati svoja plemićka prava ne želeći se podvrgnuti vlasti gradske uprave prihvaćanjem građanskog statusa. Takav izdvojeni položaj plemstva unutar grada omogućavao je i dovođenje obrtnika i trgovaca i drugih podložnika koji su bili izuzeti iz gradske jurisdikcije, što je slabilo gradsku vlast i umanjivalo gradske prihode. Ovaj status se mijenja sredinom 18. stoljeća kada plemstvo pokazuje sve veći interes za stjecanjem građanskog statusa te dolazi do postupnog pretvaranja plemstva u punopravne građane. ${ }^{45} \mathrm{U}$ 18. stoljeću dolazi do izgradnje i obnove sakralnih objekata u gradu: crkve sv. Nikole, sv. Marije, Porođenja Isusova. ${ }^{46}$ Sukladno tadašnjim „visokim standardima“ života njegovih stanovnika, Varaždin je u 18. stoljeću bio i jedan od najvažnijih obrazovnih središta. ${ }^{47}$ Tada se uz Varaždin pojavljuju pojmovi „mali Beč“, ,"bečka moda“, „, francuska kuhinja“. ${ }^{48}$ Varaždin je u 18. stoljeću prednjačio

43 Rudolf LONČARIĆ, Mirna AMADORI, „Graditeljska baština grada Varaždina“, 800 godina slobodnog kraljevskog grada Varaždina 1209.-2009., Zbornik radova, ured. Miroslav ŠICEL, Slobodan KAŠTELA, HAZU Zavod za znanstveni rad u Varaždinu, Grad Varaždin, Varaždinska županija, Zagreb-Varaždin, 2009., 501.

44 Lana GOTAL, „Kulturno značenje grada Varaždina“, Radovi Zavoda za znanstveni rad HAZU Varaždin, br.25, 2014, 573-593.

45 R. VUČETIĆ, „Predmoderni grad“, 131.-135.

46 L. GOTAL, "Kulturno značenje grada Varaždina“, 576.-578.

47 R. VUČETIĆ, „Predmoderni grad“, 139.-140.

48 Eduard KUŠEN, „Varaždinski turizam do Drugog svjetskog rata“, 800 godina slobodnog kraljevskog grada Varaždina 1209.-2009., Zbornik radova, ured. Miroslav ŠICEL, Slobodan KAŠTELA, HAZU Zavod za znanstveni rad u Varaždinu, Grad Varaždin, Varaždinska županija, Zagreb-Varaždin, 2009., 489.-493. 
i u zdravstvenoj zaštiti svojih građana jer je imao razgranatu ljekarničku ${ }^{49}$ i liječničku službu. ${ }^{50}$ Barokni Varaždin imao je i vrlo bogat kulturni život. Varaždinci su u svojim raskošnim palačama, održavali brojne zabave, krabuljne plesove i kazališne predstave. Na ulicama su se mogli vidjeti najsuvremenije kočije, livrirane sluge i teklići. Sve ovo je usporio katastrofalni požar 1776. godine, kada je bogat i raskošan život grada naglo prekinut. Nakon požara grad Varaždin brzo se obnavljao. Osnovana je „Komisija za regulatornu osnovu grada“ koja je trebala provoditi mjere zaštite od požara i urediti ulice koje su trebale biti ravnije i šire. Osim praktičnim razlozima Komisija se povodila i estetskim potrebama, poljepšavanjem ulica. Do druge polovice 18. stoljeća gradske ulice i trgovi bili su zatrpani smećem koje su građani odlagali na javne površine. Na ulice se bacalo razno smeće, zahodske jame postavljane su na ulicu da ne smrde u dvorištima, a kanali s oborinskim i otpadnim fekalnim vodama prelazili su preko ulica. Sve se to nastoji regulirati. Uposlen je poseban službenik koji se trebao brinuti za čistoću ulica i odvoženje smeća na za to predviđena mjesta izvan grada. U 18. stoljeću spominje se i ulična rasvjeta u gradu. Popločavaju se i taracaju ulice. Jedno od obilježja grada su i javni zdenci na kojima se okupljao veći broj građana. U središtu se javlja i javna skulptura, pil s prikazom Bogorodice pred Isusovačkim samostanom, a kip Imakulate postavljen je pred Franjevačkom crkvom. ${ }^{51}$ Iako su državne funkcije prebačene u Zagreb, prostorni, gospodarski i demografski razvoj grada ubrzo je početkom 19. stoljeća pokazivao pozitivne trendove razvoja. Obnavljaju se gradski i sakralni objekti. Nakon požara, gradske palače plemića preuzimaju trgovci, dajući im novu namjenu. ${ }^{52}$

\section{GRAD U 19. STOLJEĆU}

U prvoj polovici 19. stoljeća iz arhitekture varaždinske jezgre nestaje svakog traga kasnobaroknog graditeljstva, te dolazi do potpune i snažne afirmacije jednog novog stilskog izraza, $\mathrm{tj}$. građanskog stila ili klasicizma. ${ }^{53}$ Uvidom $\mathrm{u}$ planove toga vremena, vidi se da 1860. godine u Varaždinu gotovo nema drvenih kuća. Posljedica je to niza katastrofalnih požara, nakon kojih je gradsko zakonodavstvo zabranjivalo

49 Bernarda RATANČIĆ, Vladanka MILOŠEVIĆ, „Prilog poznavanju povijesti franjevačke ljekarne u Varaždinu“", Godišnjak hrvatskog restauratorskog zavoda, 7., Zagreb, 2016, 193-208.

50 Zvonko KUSIĆ, Stella FATOVIĆ FERENČIĆ, „,Od kupališnog liječnika do bolnice: razvoj zdravstva u Varaždinu do početaka 20. stoljeća“, 800 godina slobodnog kraljevskog grada Varaždina 1209.-2009., Zbornik radova, ured. Miroslav ŠICEL, Slobodan KAŠTELA, HAZU Zavod za znanstveni rad u Varaždinu, Grad Varaždin, Varaždinska županija, Zagreb-Varaždin, 2009., 863.-870.

51 R. VUČETIĆ, „Predmoderni grad“, 144.

52 Isto, 140.

53 R. LONČARIĆ, M. AMADORI, „,Graditeljska baština grada Varaždina“, 502. 
gradnju stambenih drvenih kuća. Jedine drvene kuće na području grada bile su one gospodarskog karaktera smještene u stražnjem dijelu dvorišta, dok su stambene kuće gotovo redovito zidane. Tada se oblikuje i gradsko šetalište, u kojem je od 1852. do 1869. radila slastičarnica, a od 1854. u parku je podignut glazbeni paviljon u kojem je svirala gradska glazba. Takvo uređeno šetalište postalo je omiljeno okupljalište varaždinskog građanstva i mladeži. Zahvaljujući uređenju šetališta, ali i nizu komunalnih akcija oko dijela poznatog kao grabište, taj prostor tijekom druge polovice 19. stoljeća prerasta u zonu najreprezentativnije izgradnje ne samo privatnih palača (vila Bedeković, Müller), već i javnih objekata s centralnim funkcijama. ${ }^{54}$ Iako su varaždinska predgrađa bila fizički spojena s gradskim središtem, tamo su kuće još uvijek bile znatno manje, drvene, a gotovo svaka je imala u stražnjem dvorištu gospodarske objekte iza kojih se nastavljaju vrtovi, voćnjaci, pa čak i oranice. ${ }^{55}$

Varaždin je 30ih godina 19. stoljeća doživio značajne preobrazbe u prostornoj (uređuju se novi trgovi i parkovi) i funkcionalnoj organizaciji grada koje su podigle njegov urban identitet ali i standard života njegovih građana. Godine 1838. uvodi se uljna rasvjeta. Kao i u prethodnom razdoblju sve je to omogućeno zahvaljujući snažnom gospodarstvu. Iako je izgubio funkciju glavnog grada, Varaždin je i nadalje bio jedan od najvažnijih kulturnih i političkih središta Hrvatske i jedno od najvažnijih uporišta ilirskog pokreta. Sredinom 19. stoljeća izgradnja grada nastoji se sve više institucionalizirati. Od tada djeluje Građevna komisija tj. odbor koji 1868. izrađuje "Građevni rednik za područje slobodnog i kraljevskog grada Varaždina" sa svrhom da se grad i građevine uređuju obzirom na "sigurnost, zdravlje, udobnost i ukus stanovništva“. ${ }^{56} \mathrm{U}$ drugoj polovici dolazi do afirmacije tzv. historicističkog stila. $\mathrm{U}$ tom se stilu grade monumentalne javne zgrade (kazalište, gimnazija) i velike stambene kuće. ${ }^{57}$ Od 60 -ih godina 19. stoljeća grad se širi prema periferiji u kojoj nastaju varaždinske manufakturne radionice. Krajem 19. stoljeća u gradu se rješava nekoliko važnih razvojnih pitanja (telefonska veza 1898., električna energija 1895., sportska dvorana 1897., kazalište 1873.). Osim na temeljnim komunalnim pitanjima, u to vrijeme počinje se raditi i na estetskom dotjerivanju Varaždina. Osniva se „Društvo za poljepšavanje grada“ (1888.-1897.). Društvo je djelovalo samo devet godina i najveći dio njegova djelovanja odnosio se na ozelenjivanje ulica i trgova te

\footnotetext{
54 M. SLUKAN ALTIĆ, Povijesni atlas gradova, VARAŽDIN , 143.

55 Isto, 145.

56 Mirela SLUKAN ALTIĆ, „Regulatorne osnove Varaždina i njihov utjecaj na povijesni razvoj grada“, 800 godina slobodnog kraljevskog grada Varaždina 1209.-2009., Zbornik radova, ured. Miroslav ŠICEL, Slobodan KAŠTELA, HAZU Zavod za znanstveni rad u Varaždinu, Grad Varaždin, Varaždinska županija, Zagreb-Varaždin, 2009., 78.-79.

57 R. LONČARIĆ, M. AMADORI, „Graditeljska baština grada Varaždina“, 503.
} 
uređenje parkova. ${ }^{58}$ Jedna od najvažnijih novina u Varaždinu krajem 19. stoljeća svakako je bilo njegovo povezivanje s drugim dijelovima sjeverne Hrvatske željezničkom prugom Čakovec-Varaždin-Zaprešić (1886.). ${ }^{59}$ Razvijanjem prometnica dolazi i do ulaganja vanjskog kapitala u industriju Varaždina. Uz vanjski kapital, ulaže se i domaći, pa se osnivaju financijske institucije: Varaždinska štedionica, Pučka štedionica, podružnica Prve hrvatske štedionice, podružnica AustrijskoUgarske banke te podružnica Hrvatskog trgovačkog društva Merkur. ${ }^{60}$

Sve ove pogodnosti su građanima omogućavale ipak drugačiju kvalitetu življenja nego li na selu, iako bi ovdje trebalo naglasiti, da ove pogodnosti ipak nisu bile namijenjene širokom pučanstvu već manjoj skupini građana (poduzetnicima i trgovcima) koja je pripadala srednjem sloju kao i plemstvu-višem sloju. Gradska sirotinja i nadalje nije imala neke veće koristi od pogodnosti, osim u trenucima kada se građani počinju društveno organizirati pa humanitarnim aktivnostima skrbe za siromašne. Plemstvo i srednji građanski sloj je i u svakodnevnom životu poduzimao korake prema boljoj kvaliteti života, a na to nam ukazuju palače i kuće koje su gradili, stil odijevanja, društveni i kulturni život koji se odvijao oko i kod njih.

\section{KULTURNI I DRUŠTVENI ŽIVOT U GRADU}

Iako je kazalište izgrađeno 1873., kazališni život je postajao u gradu dulje nego sama zgrada. Ne zna se točno kada je počeo zbog uništenih spisa u požaru, i vjerojatno su prve predstave bile crkvenog karaktera i odigravale su se u tadašnjim varaždinskim crkvama. U 17. stoljeću kazališne predstave održavale su se u zgradi varaždinske isusovačke gimnazije. Prve vijesti o kazališnoj predstavi datiraju iz 1673. godine, kada su krajem školske godine đaci održali predstavu s nazivom „Sveta Katarina". U drugoj polovici 18. stoljeća kazališne predstave održavale su se u obnovljenoj zgradi nekadašnje Njemačke kongregacije, a u 19. stoljeću u redutnoj dvorani koja se nalazila u zapadnom dijelu nekadašnje palače grofova Batthanyi. ${ }^{61} \mathrm{U}$ gradu je vladalo veliko zanimanje za kazalište ne samo građana već i plemstva. U grad su

${ }_{58}$ M. SLUKAN ALTIĆ, „Regulatorne osnove Varaždina“, 79. -80.; M. SLUKAN ALTIĆ, Povijesni atlas gradova, VARAŽDIN, 157.

59 Madeleine KUKEC, „Urbani razvoj grada Varaždina od 1910. do 1920. godine“, Varaždin i sjeverozapadna Hrvatska u Velikom ratu 1914.-1918., Varaždin, Zagreb-Varaždin, 2014., 301.-316.

${ }^{60}$ Franjo RUŽA, Slobodan KAŠTELA, „Povijesni uvjeti gospodarskog razvitka Varaždina“, 800 godina slobodnog kraljevskog grada Varaždina 1209.-2009., Zbornik radova, ured. Miroslav ŠICEL, Slobodan KAŠTELA, HAZU Zavod za znanstveni rad u Varaždinu, Grad Varaždin, Varaždinska županija, Zagreb-Varaždin, 2009., 339.

61 Miroslav KLEMM, „Zgrada varaždinskog gradskog kazališta“, Radovi Zavoda za znanstveni rad HAZU Varaždin, br. 25., Varaždin, 2014., 297.-306. 
povremeno dolazili profesionalni kazališni ansambli. Na prijelazu u 19. stoljeće u gradu se pojavljuju putujuće glumačke družine koje izvode sve od veselih doskočica, preko opereta do suvremenih opera. Ples je obilježio 19. stoljeće. Plesalo se svakom prilikom. Zimska sezona je bila sezona balova, kada se je plesalo u plemićkim palačama, građanskim kućama i u dvoranama prilagođenim za tu namjenu. Pripreme za plesove bile su temeljite. Plesne dvorane toga doba bile su u rangu ugostiteljskih objekata. Plemići i vlastela kopirali su raskošni i raskalašeni život na europskim dvorovima te u Varaždin uvode novu vrstu zabave. Zabava se nudila i na sajmovima. Sajmovi su bili središnje mjesto okupljanja ljudi gdje su dolazili trgovci i obrtnici iz raznih krajeva kao i seljaci iz obližnjih mjesta. Na sajmove su građani dolazili zbog kupovine, a stizali su i razni zabavljači-čarobnjaci, gutači vatre, atlete, gatare, romske družine s medvjedima, glumci komedijaši, a prostitutke su nudile svoje usluge. Bilo je mnogo prosjaka, skitnica i sitnih lopova. ${ }^{62} \mathrm{U}$ gradu se njegovalo i muziciranje, pa je u tu svrhu utemeljena 1828. Glazbena škola u okviru Glazbenog društva, s ciljem školovanja glazbeno nadarene djece čije obitelji nisu imale sredstava za takvo školovanje. Deset godina kasnije (1838.) osnovana je i Čitaonica. ${ }^{63}$

Građani svih staleža zabavljali su se na razne načine, najprije su se zabavljali šetanjem po promenadama, potom su se družili na proslavama, sudjelovali su u brojnim povorkama i zabavama na kojima je svirala gradska glazba ili su pjevali u zborovima. Neki od njih bavili su se streljaštvom, dio je bio članom vatrogasnih društava i sudjelovao je $\mathrm{u}$ vatrogasnim vježbama i zabavama, a dio članom gradskih straža i četa. Plemstvo i bogatiji vozili su se kočijama, bavili su se jahanjem, organizirali su plesove, gozbe, salonske zabave, balove, klizali su, igrali tenis. Od početka 19. stoljeća pa sve do 1914. u Varaždinu su nastali sljedeći sportovi: streljaštvo (1819. imućniji građani osnovali su „streljačko društvo“), ples (1820. varaždinsko muzičko društvo priređuje ples), kupanje i plivanje (od 1840. počeci kupanja na Dravi, a 1901. izgrađeno prvo kupalište), šah (u Kasinu se igrao šah a 1904. osnovano je Varaždinsko šah društvo), streličarstvo (1861. osnovano „Družtvo strijelaca sa rilom i sačmom“), ribolov (1860. Društvo ribostreličara koje 1913. mijenja ime u „Varaždinsko ribolovno društvo“), atletika (tjelovježbno društvo „Varaždinski sokol“), kuglanje („Varaždinski keglerski savez“ od 1884.), biciklizam (prvi bicikl u Varaždinu se pojavio 1878., a prvi biciklistički klub „Varaždinski klub biciklista“ je osnovan 1894.,

62 Eduard KUŠEN, „Varaždinski turizam do Drugog svjetskog rata“, 800 godina slobodnog kraljevskog grada Varaždina 1209.-2009., Zbornik radova, ured. Miroslav ŠICEL, Slobodan KAŠTELA, HAZU Zavod za znanstveni rad u Varaždinu, Grad Varaždin, Varaždinska županija, Zagreb-Varaždin, 2009., 489. -493. Više o glazbi vidi: Ljerka PERČI, „Prilog poznavanju glazbenog života Varaždina od 1827. do 1842.“, Radovi Zavoda za znanstveni rad HAZU Varaždin, br.19., 2008., 9.-27.

63 L. GOTAL, „Kulturno značenje grada Varaždina“, 578.-580. 
drugi 1897. pod imenom Koturaško društvo „Sloga“), planinarstvo (ideja za društvom se javila 1883., društvo je prvo osnovano 1898.u Ivancu, a u Varaždinu tek 1919. pod nazivom „PD Ivančica“), automobilizam (prvi automobil 1898., a prva utrka 1908.), konjički sport-jahanje (jahanje je u početku bilo dostupno samo časnicima, a prvo sportsko natjecanje zabilježeno je 1887. konjički sport se ipak kao takav počeo razvijati od 1918. i 1921.), mačevanje (mačevanje se pojavilo 1896. kao dio programa tjelovježbe u gimnaziji, a 1902. u Varaždinu Hrvatski sokol osniva poseban odjel za mačevanje), tenis (prije 1897. tenis su igrali artiljerijski časnici, njihove žene i kćeri, a 1907. Hrvatski sokol uvodi poseban odjel te tenis igraju članovi sokola i učenici gimnazije), klizanje (poslije 1890. pojava klizanja), boks (1909.) i hrvanje (1906.). Do Prvog svjetskog rata pojavile su se sportske igre loptom, nogomet (1907.) i rukomet (1898.). Vježbanju se sve više poklanja pažnja pa je školske godine 1857./58. u nižu realku uvedeno za dječake tjelesno vježbanje kao neobavezan predmet, potom se u gimnaziju uvodi gombanje, pa gimnastika, da bi 1909. bio osnovan i prvi učenički sportski klub „Varaždinski gimnazijski športski klub“. Grade se i sportski objekti: zgrada streljane (1820.), gradsko kupalište (1840/1863.), jačalište (1876.), gombalište (1864.), penjaći toranj za vatrogasne vježbe (1873.), tenis igrališta (1890./1910.), hipodrom i jahališta (1892.), biciklističko trkalište (1895.), gradska gombaonica (1896.), klizalište (1905.), nogometno igralište (1910.) i dr. ${ }^{64}$

Uz sport i rekreaciju, razvija se istraživački ili medicinski turizam. U bližoj i daljoj okolici Varaždina bilo je raznih lječilišta. Tako je u Krapini postojalo lječilište za liječenje hladnom vodom, a u selu Svibovcu pokraj Varaždinskih Toplica lječilište u kojem se liječilo po Schrotovoj metodi. Godišnje se ondje liječilo 300 bolesnika. Na području sjeverozapadne Hrvatske bilo je nekoliko toplica: Krapinske, Tuheljske, Sutinske i Varaždinske Toplice. ${ }^{65}$ Različita događanja, kao što su sajmovi, proštenja, proslave i drugi skupovi, u grad su privlačili brojne posjetitelje. Zbog toga se u gradu otvaraju brojna svratišta i gostionice opremljene sobama za ukonačivanje. Uz to niču razne krčme, privatne i varoške točionice vina i piva, a kasnije i kavane. ${ }^{66}$ Sva ova ugostiteljska ponuda bila je dostupna Varaždincima. Tu su se građani Varaždina susretali, družili, organizirali zabave, dolazili na ručak, čitali novine. Tu

\footnotetext{
"44 Stjepan STOLNIK, „Sport u Varaždinu“, 800 godina slobodnog kraljevskog grada Varaždina 1209.-2009., Zbornik radova, ured. Miroslav ŠICEL, Slobodan KAŠTELA, HAZU Zavod za znanstveni rad u Varaždinu, Grad Varaždin, Varaždinska županija, Zagreb-Varaždin, 2009., 889.-893.

65 Gustav PIASEK, „Nekoliko podataka o bolnicama Varaždinske županije u prošlosti“", Muzejski vjesnik, Glasilo Muzejskog društva sjeverozapadne Hrvatske, 11, Varaždin, 1988., 50.-53.

66 E. KUŠEN, „Varaždinski turizam do Drugog svjetskog rata“, 489.-493.; Ivy LENTIĆ-KUGLI, „Prilog istraživanju varaždinskih svratišta, gostionica i kavana u 18. i prvoj polovici 19. stoljeća", Godišnjak Gradskog muzeja Varaždin, 5., Gradski muzej Varaždin, Varaždin, 1975., 53-65.
} 
se odvijao kulturni, politički i društveni život. ${ }^{67}$ Varaždin je bio poznat i po novinstvu. U vremenskom razdoblju od sto godina u Varaždinu je izlazilo 28 raznih poučno-zabavnih i informativno-političkih listova. Oni su nam vrijedni izvori ne samo Varaždina već i šire okolice. Iz njih iščitavamo svakodnevne, kulturne, društvene i političke događaje. ${ }^{68}$ Društveni život odvijao se i u hotelima. Hotel „Grandhotel Novak" kasnije "Royal" bio prvi varaždinski hotel s velikom blagovaonom, kavanom i vrtnom terasom. Godine 1913. je preuređen i dobio je centralno grijanje, u njemu se jelo posluživalo sa srebrnim priborom, a kao specijalitet mogla se naručiti i gušća jetra. Postojalo je i izletište „Prater“ koje je bilo smješteno u idiličnom bukovom gaju. Na tom prostoru smještene su bile stolice i stolovi prema kojima su u predvečerje dana hrlili varaždinski građani. Tamo su gosti bili služeni jelom, pićem i raznovrsnim osvježenjima. Uz izletište je 1820. izgrađena i zgrada „Streljane“ gdje je bila dvorana za ples, blagovaona i soba za pušenje. Bilo je i drugih ugostiteljskih objekata, ne samo u središtu grada već i u predgrađu. ${ }^{69}$

\section{ZDRAVSTVENA SKRB U GRADU}

Pod konac 18. i početkom 19. stoljeća u gradu je djelovalo nekoliko liječnika, gradski fizik, kirurzi i primalje, no ipak se neprestana potreba za boljom zdravstvenom skrbi i većim brojem liječnika stalno naglašava. Građani se obraćaju Magistratu zahtijevajući bolju skrb i veći broj zdravstvenih djelatnika. U bilješkama tadašnjih liječnika (tada su ordinirala trojica) u svakodnevnoj praksi susretali su se s ovim bolestima: lues, malarija, tuberkuloza, giht, upale zglobova, glavobolje, zubobolje i uhobolje. Od zaraznih bolesti spominju se epidemični pjegavac endemičan u Mađarskoj, potom dizenterija, trbušni tifus, ospice i šarlah. Od bolesti koje su vladale spominju se skorbut, padavica i kapavac. Sudeći prema podacima koje iznose istraživači povijesti medicine na ovom području krajem i početkom 19. stoljeća nalazi se zadovoljavajući broj zdravstvenih djelatnika pa se stječe dojam da su stanovnici bili zadovoljavajuće zbrinuti. 20-ih godina 19. stoljeća u Varaždinu su tri liječnika i sedam kirurga. Premda je Varaždin bio pošteđen epidemije kolere koja je harala Europom od 1829. do 1837. ta se bolest pojavila u gradu 1849. godine. Tada je u gradu umrlo 37 osoba, a osim te bolesti bilo je još oboljelih od velikih boginja, difterije i ospica. Kolera je ponovno zaprijetila gradu 1892. godine. U gradu je tada formirano posebno zdravstveno povjerenstvo koje poduzima i karantenske izolacijske mjere. Od 1894. godine dolazi i do

\footnotetext{
67 Isto, 489.-493.

68 Tomislav ĐURIĆ, „Stare Varaždinske novine u knjižnici gradskog muzeja Varaždin“, Muzejski vjesnik, 6., ožujak, 1983., 58.-63.

69 E. KUŠEN, „Varaždinski turizam do Drugog svjetskog rata“, 489.-493.
} 
značajnijeg napretka i poboljšanja u organizaciji i provođenju zdravstvene službe. Donosi se „Zakon o uređenju zdravstvene službe“ koji uređuje da iz općina nestaju kirurzi, ranarnici i drugi nedovoljno kvalificirani praktičari, a na njihova mjesta dolaze liječnici i doktori medicine. U županijama se formiraju zdravstvene općine, samostalne ili udružene. U samom gradu krajem stoljeća bilo je 8 fizika, 2 gradska liječnika, 5 privatnih, 1 gradski veterinar, 3 ljekarnika, 2 gradske i 8 privatnih primalja. Briga za siromašne, napuštene i bolesne građane datira još iz srednjeg vijeka. Početkom 19. stoljeća u gradu su postojali hospitali koji su primali siromašne luetične ili psihički poremećene osobe. Briga za nemoćne i oboljele postupno je izrasla u organiziranu skrb ponajprije preko financijske potpore na bazi posudbe, a potom kao stečeno pravo na temelju odrednih uloga različitih oblika dobrotvornih društava. Tako je za razvoj zdravstva u Varaždinu važnu ulogu imalo humanitarno društvo „Varaždinskih dobročinstava složnost“ (1828.) koje je osnovalo prvu bolnicu (1859.). Namjena društva je bila: pomagati udovice koje su ostale bez pomoći, pomagati osobe koje se ne mogu uzdržavati zbog starosti ili siromaštva, pomagati bolesnike koji nemaju sredstva za liječenje, pomagati siromašne obitelji bez obzira na vjeru, stalež ili narodnost. Liječenje bolesnika provodio je liječnik, doktor medicine i jedan kirurg zajedno s jednim pomoćnikom. Sedam godina nakon osnivanja prve bolnice 1866. osnovana je i Javna sveopća bolnica. Međutim, ona nije zadovoljavala ni lokacijom ni arhitekturom pa se pristupilo izgradnji nove koja je izgrađena 1898., a proširena 1914. godine. U njoj su se sve do 1943. nalazili gotovo svi bolnički odjeli s izuzetkom paviljona za zarazne bolesti i paviljona za tuberkulozu. ${ }^{70}$ No to je još uvijek bilo premalo, jer kako je na početku rečeno, zdravstvena zaštita početkom 20. stoljeća i dalje je bila ograničena na samo mali broj ljudi. Još uvijek u Hrvatskoj nije bilo puno zdravstvenih djelatnika kao ni u Varaždinu, a o tome nam govore podaci iz kojih se vidi da je na početku izbijanja Prvog svjetskog rata u Hrvatskoj bilo 496 liječnika, liječnica i zubara, a od toga samo 13 u Varaždinu..$^{71}$

\section{RADNICI-GRAĐANI-PLEMSTVO}

Do sada smo govorili o okolnostima koje su omogućavale stanovnicima Varaždina da si stvore uvjete za bolji i kvalitetniji život. Naravno da je kvaliteta života ovisila i kojem društvenom sloju pripadate pa je uslijed toga i socijalna slika raznolikija. Siromašniji su ionako živjeli na rubu egzistencije, pa su odgovarajući smještaj, stanovanje, stalni posao i odgovarajuća prehrana bili u središtu njihova svakodnevna

70 Z. KUSIĆ, S. FATOVIĆ FERENČIĆ, „Od kupališnog liječnika do bolnice“, 863.-870.

71 Vladimir STRUGAR, Dubravko HABEK, „Mortalitet 16 varaždinske pukovnije u Velikom ratu 1914.1918.", Varaždin i sjeverozapadna Hrvatska u Velikom ratu 1914.-1918., Varaždin, Zagreb-Varaždin, 2014. 99.-123. 
života. Zabava, bavljenje kulturom ili sportom bile su stvari izvan dosega njihovih financija a niti su ih zanimale, jer su se bavili pukim preživljavanjem. U ovu grupu mogu se uvrstiti i radnici kojih je u gradu bilo sve više i više jer se početkom 20. stoljeća otvara u gradu nekoliko tvornica (Pamučna predionica, Tekstilna industrija „Tivar“, Tvornica savijenog pokućstva kasnije Mundus) pa dolazi do postepene migracije stanovništva iz okolnih sela u grad Varaždin. Stanovništvo polagano napušta dotadašnje bavljenje poljoprivredom i započinje se zapošljavati kao radna snaga u tim tvornicama. ${ }^{72}$ Kvaliteta života radnika i siromašnih građana u nekim segmentima je slična. Ukoliko su nastanjeni u gradu i ne dolaze na posao sa sela, radnici u gradu žive u iznajmljenim derutnim stambenim objektima u podrumima ili tavanskim prostorima i tek nekolicina ih počinje na periferiji graditi vlastite domove. Radnički najamni stanovi sastojali su se većinom od omanje sobe i još manje kuhinje, a opskrbljeni su bili najnužnijim namještajem: sobnim krevetima i ormarima, kuhinjskim stolom, stolcima bez naslona te kredencom i nevelikim metalnim štednjakom. Stanari su osobnu higijenu obavljali u kuhinji ili u prostoriji koja se nalazila na kraju kućnog hodnika gdje je bio drveni zahod bez ispiranja, zajednički za više stanova. ${ }^{73}$ Zbog radnog vremena koji je ponekad bio i cjelodnevni, nemaju previše slobodnog vremena a prehranjuju se oskudno. No ipak, neki radnici učlanjuju se u kulturna i politička društva, počinju se obrazovati, pa i zabavljati. Radnici koji su stanovali na selu i svaki dan dolazili u grad na posao za to nisu imali vremena, jer su ono malo slobodno vremena što su imali trošili na put od kuće do posla i natrag.

Uz radnike u grad se useljavaju činovnici i stručnjaci raznih struka i različitih narodnosti (Mađari, Nijemci, Česi i dr.). Oni su raspoređeni na vodeće pozicije u novo otvorenim tvornicama i njihova kvaliteta življenja je daleko bolja od radničke te oni spadaju u grupu građanstva. Kvaliteta življenja kod srednjeg i višeg građanskog sloja bila je potpuno drugačija. Uspješni i financijski sposobni građani osigurali su svojim obiteljima bolje stanovanje, prehranu, zabavu i napredak u društvu. Među njima su se počeli izdvajati privrednici i industrijalci koji su unosili promjene u društvo ne samo što su svojim kapitalom ulagali u grad, industriju, trgovinu, već su gradili arhitektonski zahtjevnije kuće, kupovali namještaj, sa putovanja donosili nove ideje koje su kulturu grada mijenjale, osnivali humanitarna društva, unosili u prehranu nove namirnice i začine pa s time se mijenjala i kultura prehrane. U prehranu se uvode topli napitci-kava i čaj. Pod utjecajem francuske kuhinje u jelovnike ulaze juhe kao uvod u glavno jelo. Uporaba vlastitog tanjura za svaku pojedinu osobu za stolom, u aristokratskim krugovima postala normom. U otmjenim kućama se uobičajeno ručalo

\footnotetext{
M. KUKEC, „Urbani razvoj grada Varaždina od 1910. do 1920. godine“, 301.-316.

73 Aleksandra MURAJ, „Svakodnevni život u 19. stoljeću“, Temelji moderne Hrvatske, Hrvatske zemlje u "dugom“ 19. stoljeću, ured. Vlasta ŠVOGER, Jasna TURKALJ, Matica hrvatska, Zagreb, 2016., 317.
} 
u podne, a večeralo oko 19 ili 20 sati. Većina namirnica kupovala se na tržnici, pekarnici ili trgovini mješovitom robom, no bilo je i dostava u kuću. Imućnije građanke obitelji imale su svoju seljanku iz obližnje okolice, koja bi svakodnevno donosila mlijeko i mliječne proizvode. ${ }^{74}$ Slično je i s odijevanjem. Odijevanje gradskog stanovništva oblikovala je moda većih kulturnih i političkih središta, koja su diktirala opći stil odijevanja s relativno brzim promjenama. ${ }^{75} \mathrm{U}$ gradu su postojale vrsne krojačice koje su šivale odjeću po zadnjoj modi, a po odjeću i obuću odlazilo se i u europske prijestolnice-Pariz i Beč. Dok je žensko odijevanje kroz cijelo 19. stoljeće bilo pod snažnim utjecajem francuske mode, muška je odjeća slijedila trendove koji su dolazili iz Londona. ${ }^{76}$ Možemo reći da nije postojala velika razlika između građanina koji je živio u Varaždinu, Zagrebu ili jednom Beču ili Budimpešti jer je nakon cestovnog i željezničkog povezivanja sve bilo dostupno samo ako ste imali mogućnosti.

No kakav je u stvarnosti bio svakodnevni život građana. Iako za Varaždin ne postoji posebna studija, možemo u nekim općim opisima iskoristiti istraživanja zagrebačke povjesničarke Iskre Iveljić koja je napisala knjigu o privrednoj eliti Zagreba u drugoj polovici 19. stoljeća. ${ }^{77}$ Nisu Varaždin niti njegova privredna elita i građanstvo previše odudarali od Zagreba. Kao i u Zagrebu, varaždinska privredna elita se sastojala i od Hrvata i od raznih doseljenika Nijemaca, Slovenaca, Mađara, Židova i drugih. ${ }^{78}$ Trgovci i obrtnici nastojali su biti uronjeni u lokalnu zajednicu. Odnos između obrtnika i trgovaca i njihovih klijenata u gradu bio je prisan. Iznimno važna je bila potpora cijele obitelji u obavljanju i sklapanju poslova. Bliži i daljnji srodnici pomagali su radom, novcem, znanjem i poslovnim kontaktima. Žene obrtnika i trgovaca vodile su kućanstvo, odgajale djecu i pomagale mužu u poslu. Kćeri i sinovi pomagali su roditeljima izborom socijalno prihvatljivog i financijski situiranog bračnog partnera, a sinovi odabirom zanimanja. Dok su sitniji trgovci i obrtnici prožimali privatni i poslovni prostor, budući da su često radili u vlastitom stanu ili kući, relativno skromnoj građanskoj prizemnici, sposobniji poslovni ljudi-poduzetnici, bankari odvajali su poslovni i privatni prostor, kupujući ili gradeći vile ili palače. Prilikom sklapanja brakova novi članovi trebali su udovoljavati socijalnim i političkim kriterijima, odnosno trebali su pripadati građanskoj eliti ili plemstvu, biti solidnog materijalnog stanja, ćudoredni, iste konfesije i katkad nacionalnosti. Premda ženidba iz ljubavi nije bila isključiva, još uvijek su bračnog druga nerijetko

\footnotetext{
A. MURAJ, „Svakodnevni život u 19. stoljeću“, 326.-330.

Isto, 331.

Isto, 339.

77 Iskra IVELJIĆ, Očevi i sinovi, privredna elita Zagreba u drugoj polovici 19. stoljeća, Zagreb, Leykam international, 2008.

78 Više u Vitomir BELAJ, „Etnografska slika varaždinskog kraja“, Varaždinski zbornik, Varaždin, 1983., 367.-380.
} 
birali roditelji, bez čijeg se blagoslova nije moglo dolično sklopiti brak. Izbor bračnog druga nije bio isključivo privatna stvar već dio opće socijalno-ekonomske obiteljske strategije. Budući zet ili snaha morali su pripadati građanskoj eliti, ali su mogli biti iz redova inteligencije, a ne samo privrednika. Brak s nekim iz plemstva bio je i dalje na cijeni. Vjenčanja takvih članova privredne elite bila su raskošna slavlja u velikom krugu obitelji i prijatelja. Obiteljski život građanstva tijekom druge polovice 19. stoljeća uvelike se promijenio. I nadalje je muškarac bio glava obitelji, no ipak su se zbile promjene u položaju žena te djece i adolescenata. Žene su se izborile za određenu autonomiju, stvorivši od svojih salona polujavni prostor kojim su vladale. Njihove socijalne obaveze bile su sve brojnije i zahtjevnije, udaljavajući ih postupno od brige za djecu i kućanskih poslova. Supruge uglednijih članova građanske elite morale su socijalnim reprezentativnim obavezama (ugodno druženje uz ukusnu hranu, zabava i pomno odabrano društvo) podupirati posao i ugled svoga supruga. Građanske obitelji su jednostavno morale ako su željele imati dobar položaj u društvu redovito priređivati objede, večere i zabave, a jednom tjedno domaćica je primala goste u svojem salonu. Osim velikih zabava, mogle su se priređivati i manje zahtjevne čajanke. Žene su imale svoje posjetnice, a djevojke bi ih dobile tek nakon što bi bile uvedene službeno u društvo. Vladanje za stolom, vođenje konverzacije, pozdravljanje, izbor odjeće, izgled posjetnica, odnos prema starijima, drugom spolu ili socijalno višim slojevima, sve je to bilo određeno društvenim normama koje su se učile. Osim primanja gostiju i odlazaka u posjete, socijalizacija je obuhvaćala i odlaske u kazalište. I tu je bio strogo određen bonton.

Od svih grana umjetnosti glazba je bila najomiljenija među građanstvom te su privrednici intenzivno sudjelovali u osnivanju glazbenih društava kao utemeljitelji, obični članovi ili jednostavno često su posjećivali glazbene priredbe. Osim odlaska u kazalište, obitelji su dokolicu provodili na raznim svečanostima i zabavama i javnim događajima (jubilejima, otkrivanje spomenika, utemeljenje tvornica). Dokolica se provodila i u šetnjama i u izletima. Slobodno vrijeme nije značilo samo ugodno druženje ili zabavu već $i$ ispunjavanje određenih obaveza nametnutih socijalnim statusom. Privrednici su zbog toga podupirali razne prosvjetne, kulturne i ekonomske inicijative i institucije, bili su angažirani u udrugama koje nisu bile najmljenje razonodi te su poticali na dobrotvorni rad. $U$ humanitarnim akcijama $u$ znatnoj mjeri sudjelovale su žene, podupirući sirotinju, djecu, mladež i ostale ugrožene skupine. Svakodnevica članova privrednih obitelji bez obzira na vjeroispovijest bila je obilježena i vjerskim obredima, molitvama i pobožnostima, redovitim odlascima u crkvu i sinagogu, proštenjima i hodočašćima ili pak obnašanjem dužnosti u vjerskoj zajednici. Djeca su manje vremena provodila s roditeljima, pa čak i s majkom, pa su se djecom bavile dadilje, guvernante te privatni učitelji i učiteljice. Nerijetko su to bile strankinje. Za razliku od starih obitelji staleškog građanstva, 
moderne građanske obitelji u svojem kućanstvu angažirale su sve više osoblja zaduženih za obnavljanje raznovrsnih usluga i zadaća: kuharica, pralja, sobarica, domara, vozača. ${ }^{79}$

O kulturi stanovanja je već nešto spomenuto u tekstu kada se govori o izgradnji grada Varaždina. No da spomenemo kakve su to bile građanske kuće, kada smo već pisali o seljačkim kućama. Te nove kuće građana, pa i varaždinskih bile su uređene u skladu s temeljenim načelima nove građanske kulture. To je značilo podjelu prostora ovisno o njegovoj funkciji, te dobi, spolu i statusu korisnika. Pritom se pazilo strogo na odvojenost nusprostorija i sobica za poslugu. Najreprezentativniji dio velikih četverosobnih do peterosobnih stanova pripadao je blagovaonici i salonu, u kojima je obitelj blagovala i primala goste. Blagovaonica je obično bila opremljena velikim stolom na razvlačenje, stolcima, kredencem u kojem se držalo posuđe i jedaći pribor te ako za to nije postojao zasebni salon, stolićem s pokojom foteljom. Zidovi su bili ukrašeni slikama, saloni su bili opremljeni stolićima, tapeciranim foteljama, tabureima te slikama. U spavaćoj sobi nalazili su se veliki krevet s noćnim ormarićima i svjetiljkama, garderobni ormar i komode. Spavaća soba služila je i kao prostor za jutarnju toaletu, pa se u njoj nalazio lavor, vrč za vodu, spužve, četke, sapun te noćna posuda. Djeca su imala dječju sobu. Namještaj je slijedio neki od historijskih stilova (gotički, renesansni, rokoko, klasicistički...) često uvožen iz Austrije i Njemačke, a posebice je omiljena bila njemačka neorenesansa poznata kao altdeutsch. Nusprostorije i sobice za poslugu nalazile su se u drugom dijelu stana, odijeljene vratima. Za svakodnevni život važni su bili i tavanski i suterensko-podrumski dijelovi kuće, te drvarnice i šupe u dvorištu. Ovdje treba naglasiti kako su stanovi građanske elite prije svega bili namijenjeni reprezentaciji, pa su najveći i najkvalitetnije opremljeni bili oni dijelovi koji su služili toj svrsi, poput salona i blagovaonice. Prostorije koje su služile održavanju higijene, pripravi hrane, odmoru ukućana, smještaju djece bile su razmjerno slabije i manje namještene ${ }^{80}$ Ovo se sve može primijeniti na bogatije varaždinske građanske obitelji dok je sitno građanstvo živjelo puno skromnije.

Plemstvo je krajem 19. stoljeća već bilo na izmaku jer se nije na vrijeme uklopilo $\mathrm{u}$ moderne tokove, niti prilagodilo novim ekonomskim i društvenim uvjetima, no bez obzira na to bili osiromašeni ili ne nisu se odricali svojih privilegija, udobnosti načina življenja u palačama, a neki su od njih kako bi zadržali i dalje taj status sklapali brakove s osobama ne plemićkog porijekla, ali iz poduzetnih bogatijih obitelji. Možemo reći oni su davali ime, a poduzetnici novac. Život plemstva odvijao se između grada i sela. Ukoliko su imali veleposjede izvan grada, na njima

\footnotetext{
9 I. IVELJIĆ, Očevi i sinovi, 324.-413. (skraćeni pregled).

80 Isto, 367.-368.
} 
su boravili znatnim dijelom godine, dok su tek dio vremena provodili u svojim palačama. Svakodnevni život plemstva u kvaliteti življenja bio sličan i na selu i u gradu. Plemićka obitelj je na vlastelinstvu živjela u središnjem objektu (dvorcu ili kuriji) uz koji su se nalazile gospodarske zgrade i razni manji objekti. Na imanju je postojao i majur ili marof kao dio posjeda na kojem su stambeni objekti za personal. Najomiljenije mjesto na majuru bila je konjušnica s radnim i jahačkim konjima na kojima su djecu učili jahati. U upravljanju imanjem plemstvo se oslanjalo na brojni personal na čelu s upraviteljem ili nadzornikom cijeloga imanja, a zasebna kategorija je bilo osoblje u dvorcu (kuharice, sluge i sluškinje...). Posebno bliski vlastelinu i njegovoj obitelji bile su guvernante i dadilje koje su se brinule o djeci i koje su uglavnom bile strankinje. Život na imanju i u gradu nije podrazumijevao samo ekonomski aspekt, nego i kulturni, prosvjetni i socijalni. Od plemstva se očekivalo da materijalnim i radnim angažmanom podupire prosvjetu, kulturu i ekonomiju mjesne zajednice, da bude utemeljiteljem ili barem članom raznih udruga i inicijativa, a od plemkinja da se ističu u dobrotvornom radu. Stambeni objekti u kojima su stanovali na selu ili i gradu bili su najreprezentativniji primjerci gradnje $u$ to vrijeme. Ne rijetko su njihovi saloni bili središte društvenih i kulturnih zbivanja. Profinjeno posuđe i namještaj pomno je birano i pripadalo je jednom od stilova kao što su barok, empire, bidermajer te historicizam. ${ }^{81}$ Kvaliteta življenja plemstva vrlo je slična svakodnevnom životu imućnijih građana, s jednom razlikom, što imućnije građane ne resi stara plemićka titula, no i to se počelo mijenjati, jer se struktura hrvatskog plemstva sredinom 19. stoljeća izmijenila te su oficiri, imućniji građani, trgovci, odvjetnici i liječnici zbog raznih zasluga stekli plemićki naslov i sačinjavali su skupinu „novog plemstva“. Novo je plemstvo oponašalo način života starog plemstva i aristokracije, a spone su bile dublje ženidbama članova starog i novog plemstva. Stapanjem plemstva i bogatijeg građanstva stvarala se nova elita ${ }^{82}$ koja je težila boljim svakodnevnim uvjetima života u vlastitom domu i izvan njega.

\section{VARAŽDIN IZMEĐU DVA SVJETSKA RATA}

Između dva svjetska rata osnovu razvoja Varaždina čini prvenstveno njegova industrija koja postaje dominantni poticajni čimbenik razvoja (Tekstilna industrija Varaždin d.d. -Tivar, Tkaonica Mariborske tekstilne tvornice d.d., Varaždinska industrija svile d.d. Varaždin - Vis.) Zahvaljujući razvoju industrije, Varaždin je

\footnotetext{
81 I. IVELJIĆ, „Anatomija jedne velikaške porodice“, 105.-129.; Mirjana GROSS, „,O položaju plemstva u strukturi elite u sjevernoj Hrvatskoj potkraj 19. i na početku 20. stoljeća", Historijski zbornik, XXXI-XXXII, Zagreb, 1978.-1979., 123.-149.; A. MURAJ, ,'Svakodnevni život u 19. stoljeću“, 309.-346.

82 M. GROSS, „O položaju plemstva“, 124.-128.
} 
u međuratnom razdoblju uspio osnažiti i svoje prometne funkcije povezivanjem Varaždina s Koprivnicom 1937. godine..$^{83}$ Istodobno je Varaždin u međuratnom razdoblju izgubio i dio svojih administrativnih središnjih funkcija jer se ukidaju županije, a bivša varaždinska županija priključena je Zagrebačkoj oblasti. Gubitak funkcije županijskog središta kao i industrijalizacija, ali i kriza 1929.-1933. je Varaždinu donijela funkcionalne promjene, ali ne i značajne demografske skokove. Istodobno je varaždinska industrija doživjela značajan razvoj jer je od 1920. do 1930. u gradu djelovalo 26 većih i manjih industrijskih poduzeća. Uslijed ekonomske krize dio institucija je propao, pa ih je do 1937. ostalo 19. U gradu su do 1937. djelovale 444 trgovačke radnje, 6 novčarskih institucija te 130 ugostiteljskih radnji. Osim toga djelovale su i 232 obrtničke radnje. Takva je gospodarska osnova grada, usprkos krizi omogućavala nastavak znatnih ulaganja u razvoj i izgradnju grada te uređenje njegove komunalne infrastrukture ${ }^{84}$ Osim obrazovnih, $u$ gradu su ojačale i zdravstvene institucije. Zbog sve većeg broja učenika 1933. podignuta je nova zgrada za potrebe Mješovite osnovne škole $u$ današnjoj ulici Petra Krešimira. Uz nju su djelovale škola Josipa Jurja Strossmayera, Privatna ženska gimnazija pri uršulinskom samostanu, a od 1940. i Rudarska škola. U zaleđu Javne gradske bolnice 1938. izgrađen je Antituberkulozni paviljon u koji je smješten antituberkulozni dispanzer. Osim gradske bolnice o zdravlju građana sada brine i Dom narodnog zdravlja. Godine 1938. u gradu je bilo pet banaka, pet knjižara, tri tiskare, dvije bolnice, dvije gimnazije, tri osnovne škole, privatna glazbena škola i dva zabavišta za djecu. Uz to u gradu su bila dva kinematografa, 500 radioaparata i oko 150 telefonskih pretplatnika. ${ }^{85}$

Građanstvo je uglavnom nastavilo živjeti životom iz prethodnog stoljeća, plemstva je bilo sve manje, njihovi posjedi bili su rascjepkani, a porastao je broj radništva. Zbog razvitka industrije, Varaždin je privlačio nove doseljenike, radnike. Kvaliteta života radništva bila je loša. Neki su od njih dolazili iz susjednih sela i na posao su putovali po nekoliko sati, dok su drugi živjeli u gradu u nehigijenskim ili neadekvatnim uvjetima. Nadnice su bile male, radilo se po cijeli dan i radni uvjeti su bili loši. Tek su 1922. u ožujku krojački radnici podnijeli zahtjev svojim poslodavcima za povišenje plaća. Na pregovorima su postignuli povišenje od $30 \%$ i osamsatno vrijeme. Godine 1926. u tvornici Tivar radilo je 600 radnika. To su bili mladi ljudi, momci i djevojke koji su na rad u tvornicu dolazili iz udaljenih mjesta čak do dva sata hoda. Radilo se unutar tri smjene po osam sati, a dio radnika radio je preko dana i do 10 sati. Plaća kvalificiranih radnika bila je 4-6 dinara na sat, a nekvalificiranih

\footnotetext{
33 M. SLUKAN ALTIĆ, Povijesni atlas gradova, VARAŽDIN, 165.

84 Isto, 165.-166.

85 Isto, 175.-178.
} 
1,50 do 3 dinara. Prosječno su tjedno mogli zaraditi od 70-180 dinara. Zbog uvjeta rada, zamora uslijed napornog i prekovremenog rada, nehigijenskih radnih prostorija radnici su pobolijevali i bio je veliki postotak onih koji su bolovali od TBC-a. ${ }^{86}$ Sve više je žena radilo po tvornicama pa se tako mijenjao i njihov položaj. Promjena položaja žena uslijedila je nakon Prvog svjetskog rata jer su žene nakon odlaska muških članova obitelji preuzele vođenje gospodarstva, pa čak i neke muške poslove i zanimanja. Nakon što je rat završio, muškarci su se vratili s bojišta, više nije bilo povratka na staro.

Društvenom i kulturni život u međuratnom razdoblju varaždinskih stanovnika bio je sve raznovrsniji. Ovdje treba istaknuti da je između 1910. i 1920. došlo do izgradnje kinematografa, kuglane, većeg broja gostioničarskih objekata. U tom razdoblju dolazi i do izgradnje nekih velebnijih stambenih kuća pa i samim time bogatijem građanstvu se poboljšava kvaliteta življenja. Varaždinci su u razdoblju 1910.-1920. aktivno počeli sudjelovati u uređenju društvenih lokacija u gradu (šetališta), gostionica te time utjecali na kvalitetu življenja u samom gradu. ${ }^{87}$ Početkom 20. stoljeća javlja se u Varaždinu i jedan novi suvremeni stilski izraz tj. secesija. ${ }^{88}$ Postojeća udomaćena tjelovježbena i sportska društva i sportski klubovi osnovani prije Prvog svjetskog rata nastavili su sa svojim dosadašnjim radom, treninzima, natjecanjima i sportskim priredbama. Između dva svjetska rata u gradu su djelovala ova sportska društva: sokolsko društvo „Hrvatski sokol“, SD „Slavija“ pri Tivaru, Varaždinsko športsko društvo i Varaždinski gimnazijski športski klub. Osnivaju se i neka nova društva: NK „,Slavija“ pri Tivaru (1931.), „Hrvatski konjički sokol“ (1924.), aeroklub „Naša krila“ (1935.) i brojni drugi. ${ }^{89}$ Prema sjećanju Varaždinaca, između dva svjetska rata u gradu je bila i javna kuća, a u određeno doba bi vlasnik javne kuće vodio svoje zaposlenice na jadan sat rekreacije. Tada su građani Varaždina imali prigodu vidjeti dame. ${ }^{90}$ Što se tiče izgradnje grada, u razdoblju između dva rata dolazi do devolarizacije gradnje, te se grade brojni novi objekti (obiteljske kuće, tvornički objekti, itd.) u jednom provincijskom i konfekcijskom stilu. ${ }^{91}$

\footnotetext{
86 Ivanka ŠTAGER, „Pregled sindikalnog pokreta varaždinskih tekstilaca između dva rata“, Godišnjak gradskog muzeja, br. 4., Varaždin, 1970., 85.-87., 98.

87 M. KUKEC, „Urbani razvoj grada Varaždina od 1910. do 1920. godine“, 301.-316.

88 R. LONČARIĆ, M. AMADORI, „Graditeljska baština grada Varaždina“, 503.

89 S. STOLNIK, „Sport u Varaždinu“, 890.-896.

90 E. KUŠEN, „Varaždinski turizam do Drugog svjetskog rata“, 493.

91 R. LONČARIĆ, M. AMADORI, "Graditeljska baština grada Varaždina“, 503.; Lea LJUBA KOCIJAN, "Arhitektura secesije u Varaždinu“, 800 godina slobodnog kraljevskog grada Varaždina 1209.-2009., Zbornik radova, ured. Miroslav ŠICEL, Slobodan KAŠTELA, HAZU Zavod za znanstveni rad u Varaždinu, Grad Varaždin, Varaždinska županija, Zagreb-Varaždin, 2009., 745.-752.
} 


\section{VARAŽDIN I KVALITETA ŽIVLJENJA NAKON 1945. GODINE}

Do zastoja dolazi za vrijeme Drugog svjetskog rata, koji je zbog ratnih prilika / neprilika utjecao na kvalitetu života, a onda se od 1945. do 1990. malim koracima počinje raditi na poboljšavanju kvalitete života, raznim državnim intervencijama, stambenim zbrinjavanjem, zapošljavanjem, za sve slojeve zdravstvenim i socijalnim osiguranjem, obaveznim školstvom, organiziranjem slobodnog vremena i dr. Ovdje treba naglasiti da se kvaliteta života u bivšoj Jugoslaviji poboljšavala, međutim ukoliko ju usporedimo s europskim zemljama još uvijek je bila vrlo niska. Kao primjer opet uzimamo Varaždin. Tijekom 50-ih godina 20. stoljeća broj stanovnika grada Varaždina rastao je strelovitom brzinom. Osnovni pokretač je bila sve snažnija industrija u kojoj je dominirala tekstilna i drvna industrija. Demografski rast bio je potaknut agrarnom krizom. Dolazi do stambene izgradnje, osim obiteljskih kuća intenzivnija je društvena stanogradnja višekatnih stambenih zgrada. Potaknut snažnim demografskim rastom u poslijeratnom razdoblju u gradu ojačale su i obrazovne funkcije. Varaždin postaje obrazovno središte za veći dio sjeverozapadne Hrvatske. Kultura se ogledala kroz djelovanje Narodnog kazališta, Gradske knjižnice i čitaonice, Gradskog muzeja, Gradskog arhiva, kinematografa te niza kulturnih i sportskih društava. Ojačava i medicinska skrb, šire se odjeli Opće gradske bolnice te Higijenskog zavoda. Grad se širi i radi se na urbanizaciji i njegovom komunalnom, prometnom, telekomunikacijskom i drugom povezivanju čime pojedinci dobivaju na boljoj kvaliteti života. ${ }^{92}$

\section{ZAKLJUČAK}

Na kraju mogu zaključiti da se kvaliteta života iz stoljeća u stoljeće mijenjala, da je bila drugačija na selu od grada, da su postojale razlike u kvaliteti života na selu između imućnijih i siromašnijih seljaka, slično kao i u gradu između siromašnih građana, radnika, obrtnika, trgovaca, poduzetnika i plemstva. Iako su se u ovom pregledu pokušale naglasiti razlike u kvaliteti života na selu i u gradu kroz povijest još uvijek postoje područja kvalitete života koja su neistražena te nam predstoje godine istraživanja.

$\overline{92}$ M. SLUKAN ALTIĆ, Povijesni atlas gradova, VARAŽDIN, 186. 


\section{LITERATURA}

1. Vitomir BELAJ, „Etnografska slika varaždinskog kraja“, Varaždinski zbornik, Varaždin, 1983., 367.-380.

2. Ante E. BRLIĆ, „U Međimurju i Varaždinu 1795.“, Muzejski vjesnik, Glasilo Muzeja sjeverozapadne Hrvatske, 4, veljača, Varaždin,1981., 57.-58.

3. Neven BUDAK, "Pogranična gradska naselja sjeverne Hrvatske u 17. stoljeću“, Radovi, Zavoda za hrvatsku povijest Filozofskog Fakulteta, 25, Zagreb, 1992., 27. -38.

4. Josip ČIČEK, „Kvaliteta života u suvremenim uvjetima u Republici Hrvatskoj s posebnim osvrtom na Bjelovarsko-bilogorsku županiju“, Radovi Zavoda za znanstvenoistraživački i umjetnički rad u Bjelovaru, sv. 7., 2013., 239.-250.

5. Nada DEŽELIĆ, Mirna ZEBEC, Josipa KERN, Željko PANTIĆ, „Zdravstveno -ekološki aspekti stanovanja u selima Hrvatskog zagorja“, Sociologija sela, 22, 83/86, Zagreb, 1984., 73.-83.

6. Tomislav ĐURIĆ, „Stare Varaždinske novine u knjižnici gradskog muzeja Varaždin", Muzejski vjesnik, Glasilo muzeja sjeverozapadne Hrvatske, vol. 6., ožujak, 1983., 58.-63.

7. Lana GOTAL, „Kulturno značenje grada Varaždina“, Radovi Zavoda za znanstveni rad HAZU Varaždin, br.25, 2014, 573-593.

8. Hrvoje GRAČANIN, Silvija PISK, „Sjeverozapadna Hrvatska u ranom srednjem vijeku", Povijest Hrvata I., Nova zraka u europskom svjetlu, Hrvatske zemlje u ranom srednjem vijeku (oko 550-oko 1150), urednica Zrinka NIKOLIĆ JAKUS, Zagreb, Matica Hrvatska, 2016., 331.-370.

9. Mirjana GROSS, O položaju plemstva u strukturi elite u sjevernoj Hrvatskoj potkraj 19. i na početku 20. stoljeća, Historijski zbornik, XXXI-XXXII, Zagreb, 1978.-1979., 123.-149.

10. Iskra IVELJIĆ, Očevi i sinovi, privredna elita Zagreba u drugoj polovici 19. stoljeća, Zagreb, Leykam international, 2008.

11. Iskra IVELJIĆ, Anatomija jedne velikaške porodice. Rauchovi, FF press, Zagreb, 2014.

12. Ivana JUKIĆ, Maja KATUŠIĆ, "Svakodnevlje“, U potrazi za mirom i blagostanjem, Hrvatske zemlje u 18. stoljeću, ur. Lovorka ČORALIĆ, Povijest Hrvata, sv.5., Zagreb, Matica hrvatska, 2013., 233.- 254.

13. Ljiljana KALITERNA LIPOVČAN, Josip BURUŠIĆ, Maja TADIĆ, „Indikatori kvalitete življenja" u: Viktor BOŽIČEVIĆ, Siniša BRLAS, Marina GULIN, 
Psihologija u zaštiti mentalnog zdravlja, Priručnik za psihološku djelatnost i promicanju mentalnog zdravlja, Virovitica, 2012., 438.-445.

14. Miroslav KLEMM, „Zgrada varaždinskog gradskog kazališta“, Radovi Zavoda za znanstveni rad HAZU Varaždin, br. 25., Varaždin, 2014., 297.-306.

15. Madeleine KUKEC, „Urbani razvoj grada Varaždina od 1910. do 1920. godine“, Varaždin i sjeverozapadna Hrvatska u Velikom ratu 1914.-1918., Varaždin, ZagrebVaraždin, 2014., 301.-316.

16. Zvonko KUSIĆ, Stella FATOVIĆ FERENČIĆ, „,Od kupališnog liječnika do bolnice: razvoj zdravstva u Varaždinu do početaka 20. stoljeća", 800 godina slobodnog kraljevskog grada Varaždina 1209.-2009., Zbornik radova, ured. Miroslav ŠICEL, Slobodan KAŠTELA, HAZU Zavod za znanstveni rad u Varaždinu, Grad Varaždin, Varaždinska županija, Zagreb-Varaždin, 2009., 863.-870.

17. Eduard KUŠEN, „,Varaždinski turizam do Drugog svjetskog rata“, 800 godina slobodnog kraljevskog grada Varaždina 1209.-2009., Zbornik radova, ured. Miroslav ŠICEL, Slobodan KAŠTELA, HAZU Zavod za znanstveni rad u Varaždinu, Grad Varaždin, Varaždinska županija, Zagreb-Varaždin, 2009., 489. -493.

18. Suzana LEČEK, „Seljačka obitelj u Hrvatskoj 1918.-1960., Metoda usmene povijesti“, Radovi, Zavoda za hrvatsku povijest, vol. 29., Zagreb, 1996., 249.-265.

19. Suzana LEČEK, Seljačka obitelj u sjeverozapadnoj Hrvatskoj 1918.-1941., Zagreb, 2003.

20. Ivy LENTIĆ-KUGLI, „Prilog istraživanju varaždinskih svratišta, gostionica i kavana u 18. i prvoj polovici 19. stoljeća“, Godišnjak Gradskog muzeja Varaždin, vol. 5., Gradski muzej Varaždin, Varaždin, 1975., 53-65.

21. Rudolf LONČARIĆ, Mirna AMADORI, "Graditeljska baština grada Varaždina“, 800 godina slobodnog kraljevskog grada Varaždina 1209.-2009., Zbornik radova, ured. Miroslav ŠICEL, Slobodan KAŠTELA, HAZU Zavod za znanstveni rad u Varaždinu, Grad Varaždin, Varaždinska županija, Zagreb-Varaždin, 2009., 499.-509.

22. Lea LJUBA KOCIJAN, „Arhitektura secesije u Varaždinu“, 800 godina slobodnog kraljevskog grada Varaždina 1209.-2009., Zbornik radova, ured. Miroslav ŠICEL, Slobodan KAŠTELA, HAZU Zavod za znanstveni rad u Varaždinu, Grad Varaždin, Varaždinska županija, Zagreb-Varaždin, 2009., 745.-752.

23. Aleksandra MURAJ, Svakodnevni život u 19. stoljeću, Temelji moderne Hrvatske, Hrvatske zemlje u "dugom" 19. stoljeću, ured. Vlasta ŠVOGER, Jasna TURKALJ, Matica hrvatska, Zagreb, 2016., 309.-346.

24. Dražen NJEGAČ, „Oblici prostorne mobilnosti stanovništva Hrvatskog zagorja“, Geografski glasnik, 57, Zagreb, 1995, 93.-109. 
25. Dragutin PAVLIČEVIĆ, Hrvatske kućne zadruge I. (do 1881), Zagreb, 1989.

26. Dragutin PAVLIČEVIĆ, Hrvatske kućnelobiteljske zadruge I., (do 1881.), drugo, ponovljeno izdanje, Golden Marketing-tehnička knjiga, Zagreb, 2010.

27. Ljerka PERČI, „Prilog poznavanju glazbenog života Varaždina od 1827. do 1842.“, Radovi Zavoda za znanstveni rad HAZU Varaždin, br.19., 2008., 9.-27.

28. Gustav PIASEK, „Nekoliko podataka o bolnicama Varaždinske županije u prošlosti“", Muzejski vjesnik, Glasilo Muzejskog društva sjeverozapadne Hrvatske, 11, Varaždin, 1988., 50.-53.

29. Gustav PISEK, „Nekoliko podataka o bolnicama Varaždinske županije u prošlosti“", Muzejski vjesnik, glasilo Muzejskog društva sjeverozapadne Hrvatske, 11, ožujak, Varaždin, 1988, 50.-53.

30. Bernarda RATANČIĆ, Vladanka MILOŠEVIĆ, „Prilog poznavanju povijesti franjevačke ljekarne u Varaždinu“, Godišnjak hrvatskog restauratorskog zavoda, 7. , Zagreb, 2016, 193-208.

31. Milivoj REĐEP, Miroslav ŽUGAJ, „Kućne zadruge u Varaždinskoj županiji u drugoj polovici 19. i početkom 20. Stoljeća“, Radovi Zavoda za znanstveni rad HAZU Varaždin, br.4.-5., 1990.-1991., 89.-110.

32. Franjo RUŽA, Slobodan KAŠTELA, „Povijesni uvjeti gospodarskog razvitka Varaždina“, 800 godina slobodnog kraljevskog grada Varaždina 1209.-2009., Zbornik radova, ured. Miroslav ŠICEL, Slobodan KAŠTELA, HAZU Zavod za znanstveni rad u Varaždinu, Grad Varaždin, Varaždinska županija, Zagreb-Varaždin, 2009., 333.-344.

33. Lana SLAVUJ, „,Objektivni i subjektivni pokazatelji u istraživanju koncepta kvalitete života", Geoadria, 17/1, Zadar, 2012., 73-92.

34. Mirela SLUKAN ALTIĆ, „Regulatorne osnove Varaždina i njihov utjecaj na povijesni razvoj grada", 800 godina slobodnog kraljevskog grada Varaždina 1209.-2009., Zbornik radova, ured. Miroslav ŠICEL, Slobodan KAŠTELA, HAZU Zavod za znanstveni rad u Varaždinu, Grad Varaždin, Varaždinska županija, ZagrebVaraždin, 2009., 78.-79.

35. Mirela SLUKAN ALTIĆ, Povijesni atlas gradova, VARAŽDIN, V. svezak, Institut društvenih znanosti Ivo Pilar, Državni arhiv Varaždin, Varaždin, 2009., 73.-84.

36. Božica SOMEK-MACHALA, „Utjecaj kulturnih promjena na prehranu stanovništva uz Sutlu“, Studia ethnologica, vol.1., Zagreb, 1989., 202. -206.

37. Stjepan STOLNIK, „Sport u Varaždinu“, 800 godina slobodnog kraljevskog grada Varaždina 1209.-2009., Zbornik radova, ured. Miroslav ŠICEL, Slobodan KAŠTELA, 
HAZU Zavod za znanstveni rad u Varaždinu, Grad Varaždin, Varaždinska županija, Zagreb-Varaždin, 2009., 889.-893.

38. Vladimir STRUGAR, Dubravko HABEK, „Mortalitet 16 varaždinske pukovnije u Velikom ratu 1914.-1918.", Varaždin i sjeverozapadna Hrvatska u Velikom ratu 1914.1918., Varaždin, Zagreb-Varaždin, 2014., 99.-123.

39. Ivanka ŠTAGER, „Pregled sindikalnog pokreta varaždinskih tekstilaca između dva rata", Godišnjak gradskog muzeja, br. 4., Varaždin, 1970., 85.-87., 98.

40. Ratko VUČETIĆ, „Predmoderni grad sjeverozapadne Hrvatske-primjer Varaždina“", Radovi Instituta za povijest umjetnost, 31., Zagreb, 2007, 135.

41. Zdravko ŽIVKOVIĆ, Hrvatsko tradicijsko graditeljstvo, Zagreb, 2013.

\section{SAŽETAK}

\section{KVALITETA ŽIVLJENJA U SJEVEROZAPADNOJ HRVATSKOJ KROZ POVIJEST S NAGLASKOM NA GRAD VARAŽDIN}

U članku autorica piše o kvaliteti življenja u sjeverozapadnoj Hrvatskoj koja se stoljećima mijenjala te je drugačija bila na selu u odnosu na grad. Sve do početka 20. stoljeća na prostoru sjeverozapadne Hrvatske vrlo se teško živjelo Na selu je vladalo siromaštvo, obitelji su bile mnogobrojne, stambene prilike ne baš povoljne, kanalizacije i vodovoda nije bilo. Poljoprivreda je bila glavno zanimanje, a ona je ovisila o klimatskim prilikama tj. neprilikama, pa je prehrana je bila jednolična i nedovoljna. Sanitarni i higijenski uvjeti bili su skoro pa nepoznati, školovanje osnovno ili nikakvo, a zdravstvena zaštita minimalna. U takvom okružju u većini seoskih sredina o kvalitetama života koje danas postoje nije se previše razmišljalo, niti govorilo. Takvo stanje, uz izuzetke, vladalo je na selu pa skoro do sredine 20 . stoljeća, a negdje i kasnije. U usporedbi sa selom, nešto je drugačija kvaliteta života kod pojedinaca koji su stanovali u gradu ili većim mjestima. Niti građani o kvaliteti života nisu razmišljali ali su poduzimali korake da si „uljepšaju“ kvalitetu života, ne samo u osobnom životu, već su uređivali i okolinu u kojoj su živjeli. U radu autorica na primjeru Varaždina piše o kvaliteti života u gradu koja se kao i na selu iz stoljeća u stoljeće mijenjala, ali na drugačiji način. U gradu su postojale razlike, između kvalitete života kod radnika, trgovaca, obrtnika, građanstva i plemstva. Navedeni primjeri u radu potvrđuju da se kvaliteta življenja na selu i u gradu mijenjala iz stoljeća u stoljeće i ono što je bilo kvalitetno u 18. stoljeću, u 19. više nije, a najveći pomaci zabilježeni su u 20. stoljeću.

Ključne riječi: kvaliteta življenja; sjeverozapadna Hrvatska; selo; Varaždin. 


\section{SUMMARY}

\section{THE QUALITY OF LIFE IN NORTHWEST CROATIA THROUGH HISTORY WITH EMPHASIS ON THE CITY OF VARAŽDIN}

The author writes about the quality of life in northwest Croatia, which changed through the centuries and was different in rural and urban areas. Life in northwest Croatia before the beginning of the $20^{\text {th }}$ century was very hard - poverty was widespread in the villages, families were large, living conditions unfavourable, sewers and waterworks non-existent. Most people worked in agriculture, which was dependent on the climate and weather conditions (which were often bad), while food was monotonous and lacking. Sanitation and hygiene were almost unknown, education was basic or non-existent, and healthcare was minimal. In such conditions, the qualities of live such as exist today were rarely thought or spoken about. With some exceptions, this state of affairs in the countryside lasted almost until the mid- $20^{\text {th }}$ century or, in some places, persisted even longer. When compared to the countryside, the quality of life of people residing in cities or towns was somewhat different. Such people also didn't think much about quality of life, but they did take steps to "beautify" it, not only in their private lives, but also by changing the surroundings in which they lived. In this work, the author uses the example of Varaždin to show how the quality of life in the city, like that in the countryside, changed from century to century, albeit in different ways. In the city, there were differences in the quality of life of workers, traders, craftsmen, middle class, and nobles. The examples mentioned in this work confirm that the quality of life both in the countryside and the city changed from century to century, that that which was of good quality and rarely available in the $18^{\text {th }}$ century became more common in the $19^{\text {th }}$ century, and that the greatest changes were recorded in the $20^{\text {th }}$ century.

Key Words: Quality of life; Northwest Croatia; village; Varaždin. 